\title{
The Antioxidant Effect of Colombian Berry (Vaccinium meridionale Sw.) Extracts to Prevent Lipid Oxidation during Pork Patties Shelf-Life
}

\author{
Márcio Vargas-Ramella ${ }^{1,2}{ }^{\mathbb{D}}$, José M. Lorenzo ${ }^{2,3} \mathbb{D}$, Sol Zamuz ${ }^{2} \mathbb{D}$, María Esperanza Valdés ${ }^{4} \mathbb{D}$, Daniel Moreno ${ }^{4}(\mathbb{D}$, \\ María C. Guamán Balcázar ${ }^{5}$, José M. Fernández-Arias ${ }^{5} \mathbb{D}$, Jorge F. Reyes ${ }^{5}$ and Daniel Franco ${ }^{2, * \mathbb{D}}$ \\ 1 Centro de Educação Superior da Região Sul—CERES da Universidade do Estado de Santa Catarina, \\ Laguna 88790-000, Brazil; marcio.ramella@hotmail.com \\ 2 Centro Tecnológico de la Carne de Galicia, Rúa Galicia N 4, Parque Tecnológico de Galicia, San Cibrao das \\ Viñas, 32900 Ourense, Spain; jmlorenzo@ceteca.net (J.M.L.); solzamuz@ceteca.net (S.Z.) \\ 3 Área de Tecnología de los Alimentos, Facultad de Ciencias de Ourense, Universidad de Vigo, \\ 32004 Ourense, Spain \\ 4 Centro de Investigaciones Científicas y Tecnológicas de Extremadura (CICYTEX), Instituto Tecnológico \\ Agroalimentario de Extremadura (INTAEX), Av. Adolfo Suárez s/n, 06007 Badajoz, Spain; \\ esperanza.valdes@juntaex.es (M.E.V.); daniel.moreno@juntaex.es (D.M.) \\ 5 Departamento de Química, Universidad Técnica Particular de Loja, San Cayetano Alto s/n, \\ Loja 1101608, Ecuador; mcguaman@utpl.edu.ec (M.C.G.B.); jmfernandez@utpl.edu.ec (J.M.F.-A.); \\ jfreyes@utpl.edu.ec (J.F.R.) \\ * Correspondence: danielfranco@ceteca.net
}

Citation: Vargas-Ramella, M.; Lorenzo, J.M.; Zamuz, S.; Valdés, M.E.; Moreno, D.; Balcázar, M.C.G.; Fernández-Arias, J.M.; Reyes, J.F.; Franco, D. The Antioxidant Effect of Colombian Berry (Vaccinium meridionale Sw.) Extracts to Prevent Lipid Oxidation during Pork Patties Shelf-Life. Antioxidants 2021, 10, 1290 https://doi.org/10.3390/

antiox10081290

Academic Editor: Jeffrey B. Blumberg

Received: 5 July 2021

Accepted: 10 August 2021

Published: 14 August 2021

Publisher's Note: MDPI stays neutral with regard to jurisdictional claims in published maps and institutional affiliations.

Copyright: (c) 2021 by the authors Licensee MDPI, Basel, Switzerland. This article is an open access article distributed under the terms and conditions of the Creative Commons Attribution (CC BY) license (https:// creativecommons.org/licenses/by/ $4.0 /)$.

\begin{abstract}
A scarce amount of knowledge about the use of Colombian berry $(\mathrm{CB})$ in meat products is available in the literature. This work studies the impact of the addition of CB extracts (CBE) on pork patties at three different concentrations in the range $250-750 \mathrm{mg} / \mathrm{kg}$. CBE were characterized in terms of their polyphenolic profile and antioxidant activity [1,1-diphenyl-2-picrylhydrazyl (DPPH) radical scavenging capacity, half maximal inhibitory antioxidant concentration $\left(\mathrm{IC}_{50}\right), 2,2^{\prime}$-azino-bis3-ethylbenzothiazoline-6-sulfonic acid (ABTS), ferric reducing antioxidant power assay (FRAP) and oxygen radical absorbance capacity (ORAC) tests)]. After pork patties elaboration, instrumental and sensorial colour, as well as lipid oxidation measured as thiobarbituric acid reactive substances assay (TBARS) values, were evaluated for 10 days of refrigerated storage in a modified atmosphere $(80 \%$ $\mathrm{O}_{2}-20 \% \mathrm{CO}_{2}$ ). The total anthocyanin composition represented $35 \%$ of the polyphenolic substances of the $\mathrm{CBE}$, highlighting high contents in cyanidin derivatives. Additionally, other flavonoids (quercetin and kaempferol compounds) and phenolics acids, substances positively related to antioxidant activity, were identified and quantified. In addition, the incorporation of CBE resulted in improvements in colour and lipid stability of pork patties, especially for the highest concentration used. Our findings demonstrated that $\mathrm{CBE}$ could be added to pork patties without impairing their sensorial profile. Overall, our results indicate that the use of CBE as a source of natural antioxidant, natural colourant, or even as a functional ingredient could be promising, but more studies are necessary to confirm it.
\end{abstract}

Keywords: lipid oxidation; phenolic compound; pork patties; natural antioxidant; sensory analysis; Vaccinium meridionale Sw.

\section{Introduction}

Ground meat products (e.g., patties, burgers) are widely acknowledged around the world due to their ease of preparation and consumption in terms of cooking time, as well as their nutritive inherent value [1,2]. However, despite this fact, these meat products have high water content and low levels of antioxidant compounds, hence they are prone to lipid oxidation [3]. It is well established that food oxidation processes can promote the degradation of fat-soluble vitamins and essential fatty acids as well as generate potentially harmful compounds [4]. Furthermore, several studies have identified that meat patties 
oxidize more rapidly than whole cuts as grinding disintegrates muscular membranes, releasing compounds that favour reactions among prooxidant molecules and unsaturated compounds [2]. Therefore, processing methods of pork patties make them liable to develop oxidative rancidity during elaboration and storage, resulting in an important cause of quality deterioration (e.g., flavour, colour, and texture) [5]. From these meat quality attributes, colour is the most important since it is an indicator of freshness and has a crucial influence on the consumer purchase decision. Specifically in meat products, the oxidation of heme proteins results in a deterioration of meat colour during storage [6] Consequently, these changes in organoleptic attributes may result in shelf life reduction, consumer dissatisfaction, and product rejection [1].

In this context, the usage of synthetic antioxidants is one of the major approaches for preventing these oxidative reactions and extend the meat products shelf life. However, these additives have various negative healthy connotations [7]. Considering this, in recent years, researchers and the meat industry have focused on natural ingredients from plants and fruits as an alternative to synthetic antioxidants [8-11]. Furthermore, ascorbic acid is widely used in the food industry for its antioxidant and stabilising ability [10]; although it is naturally present in fruits and some vegetables, it is economically obtained by chemical synthesis for its use as an additive. Those extracts from plants and fruits (seeds, peels, barks, woods, flowers, and leaves) that are recognized as GRAS (generally recognized as safe) have a broad acceptance from consumers [2] and usually, they are rich in phenolic compounds which have important antioxidant and antimicrobial activity [3,12-15].

Concerning their application in meat products, a large variety of fruit extracts have been reported to be effective in the improvement of the meat oxidative stability, highlighting berries especially for the phenolic compounds and vitamins ( $C$ and $E$ ) as reviewed by Lorenzo et al. [16]. Wild bilberries are known for their bioactive properties and their antioxidant capacity, attributed to their high content and variety of polyphenolic compounds [12,17]. Within berries, the genus Vaccinium comprises a group of plants that includes up to 450 species and the berries of many of them are widely consumed by humans. In particular, the Colombian berry (Vaccinium meridionale Sw.), also known as Colombian bilberry, "agraz", Andean berry, or "mortiño", is one of the species that grow in the Andean region of South America. Garzón et al. [18] reported that this fruit has high antioxidant activity and potential applications as a source of phytochemicals in the nutraceutical and functional food market because it is an excellent source of dietary phytochemicals such as polyphenolics compounds. More recently, several studies have been conducted to determine the phenolic profile of Colombian berry $[19,20]$, as well as the application of Colombian berry extract (CBE) as an antioxidant in beef patties [21]. However, the assessment of CBE as a natural antioxidant in meat products is still scarce. Considering that pork is the most widely eaten meat in the world $(>36 \%$ of the world intake) [22] and that patties are popular products in the fast-food industry, stores, restaurants, and households [2] with a limited shelf-life, it would be of interest to assess the CBE as an antioxidant.

Therefore, the present study aimed to investigate the effects of the addition of a CBE, its physicochemical ( $\mathrm{pH}$, colour, and lipid oxidation) characteristics, and the sensory quality of pork patties during nine days of refrigerated storage. Moreover, the phenolic profile and antioxidant capacity of the CBE have been carried out.

\section{Materials and Methods}

\subsection{Plant Material}

The fruits (V. meridionale Sw.), were collected from Cañi (Tangabana of Chimborazo province, Ecuador). The fruit was washed and disinfected with a chlorine solution (100 ppm). Berry processing was carried out in a brand pulper (KitchenAid ${ }^{R}$, St. Joseph, MI, USA) with a mesh size of $2 \mathrm{~mm}$ to obtain the by-product of $V$. meridionale Sw. 


\subsection{Colombian Berry (V. meridionale Sw.) Extraction Procedures—Preparation of Ethanolic Extract from Colombian Berry (CBE)}

Colombian berries (V. meridionale Sw.) were dried at $40{ }^{\circ} \mathrm{C}$ for $12 \mathrm{~h}$ in a tray dryer (DY-110H, Daeyeong E\&B CO., Ltd., Ansan, South Korea). Samples were ground, sifted, and homogenized (particle size range $<350 \mu \mathrm{m}$ ) before extraction and were stored at refrigerated conditions until the process was carried out. Extraction conditions were carried out as follows: a solid (berry) to liquid (solvent) ratio of 1:5 $(\mathrm{g} / \mathrm{mL})$ was used, as well as ethanol/water $(50: 50 \mathrm{v} / \mathrm{v})$ for three days at refrigerated temperature. Afterwards, the ethanolic Colombian berry extract was evaporated in a rotavapor (G1, Heidolph, Schwabach, Germany) at $40{ }^{\circ} \mathrm{C}$ and $150 \mathrm{rpm}$. Finally, the extract was frozen at $-40^{\circ} \mathrm{C}$ and lyophilized in freeze-drying (Labconco, Kansas City, MO, USA) with the following settings (pressure $=0.180 \mathrm{mbar}$; temperature $=-50^{\circ} \mathrm{C}$ ) for $48 \mathrm{~h}$. After freeze-drying, the Colombian berry extract obtained (CBE) was added to pork patties in different doses, as described in the Section 2.4.

\subsubsection{In Vitro Antioxidant Activity of CBE}

To assess the antioxidant activity of the CBE by four different tests, the lyophilized extract was dissolved in methanol in a ratio solid $(\mathrm{mg})$ : liquid $(\mathrm{mL})$ of 3:1 for $30 \mathrm{~min}$ at room temperature. The 1,1-diphenyl-2-picrylhydrazyl (DPPH) radical scavenging capacity was determined in CBE using $2 \mathrm{~mL}$ of a $6 \times 10^{-5} \mathrm{M}$ methanolic solution of DPPH, which was mixed with $50 \mu \mathrm{L}$ of a methanolic solution of the lyophilized extract. The inhibition percentage (IP) was calculated as the percentage reduction in absorbance at $515 \mathrm{~nm}$ after $16 \mathrm{~min}$ to the initial value and the half maximal inhibitory antioxidant concentration $\left(\mathrm{IC}_{50}\right)$ as the concentration of extract required to quench $50 \%$ of the initial DPPH radical. The results for DPPH and $\mathrm{IC}_{50}$ were expressed as $\mu \mathrm{g}$ of Trolox equivalents (TE)/g and $\mathrm{mg} / \mathrm{mL}$, respectively.

The 2,2'-Azino-Bis-3-Ethylbenzothiazoline-6-Sulfonic Acid (ABTS ${ }^{\bullet+}$ ) assay was performed following the protocol described by Re et al. [23]. This method is based on the scavenging of ABTS cation radical observed as a decolourization of the blue-green colour at $734 \mathrm{~nm}$. Solutions of $7 \mathrm{mM} \mathrm{ABTS}^{\bullet+}$ and $2.45 \mathrm{mM}$ potassium persulfate in phosphate buffer saline (PBS, pH 7.4) stood overnight to generate the $\mathrm{ABTS}^{\bullet+}$ radical cation (ABTS ${ }^{\bullet+}$ ). Then, the $\mathrm{ABTS}^{\bullet+}$ stock solution was diluted with PBS and equilibrated at $30^{\circ} \mathrm{C}$ to an absorbance of $0.8-0.9$ at $734 \mathrm{~nm}$ (PerkinElmer ${ }^{\circledR}$ Lambda $25 \mathrm{UV} /$ Vis spectrophotometer, PerkinElmer Inc., Massachusetts, MA, USA). Triplicate determinations were performed by mixing $100 \mu \mathrm{L}$ of methanolic solution of the lyophilized extract with $1.9 \mathrm{~mL}$ of radical solution. The decline in absorbance was followed for $10 \mathrm{~min}$. Appropriate solvent blanks were run for each sample. The radical scavenging capacity was compared with that of Trolox; these results are expressed as $\mathrm{g}$ of ascorbic acid per $\mathrm{kg}$ of extract.

The oxygen radical absorbance capacity (ORAC) assay was realized following the procedure described previously by Quintero-Quiroz et al. [20]. 2,2'-Azobis-(2-amidinopropane)dihydrochloride (AAPH) was used as the peroxyl radical generator, Trolox as the standard, and fluorescein as the fluorescent probe. Fluorescein, AAPH, and samples were prepared in a 75-mmol buffer at $\mathrm{pH}$ 7.4. The methanolic solution of the lyophilized extract $(3 \mathrm{mg} / \mathrm{mL})$ or Trolox standards $(25 \mu \mathrm{L})$ was mixed with $150 \mu \mathrm{L}$ of $1 \mu \mathrm{mol} / \mathrm{L}$ fluorescein and pre-incubated at $37^{\circ} \mathrm{C}$ for $30 \mathrm{~min}$ before $25 \mu \mathrm{L}$ of AAPH solution $(200 \mathrm{mmol} / \mathrm{L})$ was added. The fluorescence at an excitation wavelength of $485 \mathrm{~nm}$ and an emission wavelength of $520 \mathrm{~nm}$ was measured every 2 min for 120 min using a Spectra Max Gemini EM (Molecular Devices, Orleans Dr, Sunnyvale, CA, USA). A calibration curve with Trolox $(12.5-100 \mu \mathrm{mol} / \mathrm{L})$ was performed for quantification purposes. The results are expressed as mg of Trolox equivalents (TE) per $g$ of sample.

The ferric reducing antioxidant power (FRAP) reagent was freshly prepared with $25 \mathrm{~mL}$ of $300 \mathrm{mmol} / \mathrm{L}$ acetate buffer (pH 3.6), $2.5 \mathrm{~mL}$ of a $10 \mathrm{mmol} / \mathrm{L}$ solution of 2 , 4, 6-tripyridyl-s-triazine in $40 \mathrm{mmol} / \mathrm{L} \mathrm{HCl}$, and $2.5 \mathrm{~mL}$ of $20 \mathrm{mmol} / \mathrm{L} \mathrm{FeCl}_{3} \cdot 6 \mathrm{H}_{2} \mathrm{O}$ in distilled water. This solution was used as a blank, and a solution of $1 \mathrm{mM}$ ascorbic 
acid was used for calibration. Three $\mathrm{mL}$ of the FRAP reagent was mixed with $100 \mu \mathrm{L}$ of extracts, and the absorbance was monitored at $593 \mathrm{~nm}$. $\mathrm{FeSO}_{4}$ aqueous solutions were used for calibration. Reducing power was determined in $1 \mathrm{~mL}$ of methanolic solution of the lyophilized extract which was mixed with $2.5 \mathrm{~mL}$ of $0.2 \mathrm{M}$ phosphate buffer ( $\mathrm{pH}$ 6.6) and $2.5 \mathrm{~mL}$ of $1.0 \%$ potassium ferricyanide. The mixture was incubated at $50{ }^{\circ} \mathrm{C}$ for $30 \mathrm{~min}$ and, after the addition of $2.5 \mathrm{~mL}$ of $10 \%$ trichloroacetic acid, it was centrifuged. Then, 2.5 $\mathrm{mL}$ of the supernatant was mixed with $2.5 \mathrm{~mL}$ of water and $0.5 \mathrm{~mL}$ of $0.1 \%$ ferric chloride, before reading the absorbance at $700 \mathrm{~nm}$. The activity was expressed as mol ferric sulphate $\left(\mathrm{Fe}^{2+}\right)$ per $\mathrm{kg}$.

2.2.2. Characterization of Colombian Berry ( $V$. meridionale Sw.) Extracts: Total Phenolic Content (TPC), Total Anthocyanin Content (TAC), and Phenolic Profile

To investigate the CBE polyphenolic profile, $25 \mathrm{~mL}$ of methanol/formic acid $(95: 5 \mathrm{v} / \mathrm{v})$ solution was added to $5 \mathrm{~g}$ of the lyophilized CBE. The mixture was sonicated for $20 \mathrm{~s}$ at room temperature (Reax control, Heidolph Instruments, Schwabach, Germany) and kept in the dark for $72 \mathrm{~h}$. Upon centrifugation $\left(14,000 \mathrm{rpm}\right.$ at $4{ }^{\circ} \mathrm{C}$ for $\left.10 \mathrm{~min}\right)$, the supernatant with polyphenolic substances was collected and stored in the fridge until the analysis.

The total polyphenol content (TPC) in the methanolic acid extract was determined according to Singleton and Rossi [24] and the total anthocyanin (TAC) content was quantified by the $\mathrm{pH}$ differential method [25]. These determinations were carried out using an autoanalyzer (Y15, Biosystems, Barcelona, Spain). Total phenolics and total anthocyanin were estimated as mg of gallic acid equivalents (GAE) and malvidin-3-glycoside chloride, respectively.

High performance liquid chromatography (HPLC) separation, identification, and quantification of polyphenols substances were performed on an Agilent 1200 LC system (Agilent Technologies, Palo Alto, CA, USA), equipped with a degasser, quaternary pump, column oven, 1290 infinity autosampler, UV-Vis diode-array detector (DAD), fluorescence spectrophotometer detector (FLD), and the Chemstation software package for LC 3D systems (Agilent Technologies, Palo Alto, CA, USA) to control the instrument and for data acquisition and analysis. Separation was performed in a Licrospher ${ }^{\circledR} 100$ RP-18 reversedphase column $(250 \times 4.0 \mathrm{~mm} ; 5 \mu \mathrm{m}$ packing; Agilent Technologies, Palo Alto, CA, USA) with pre-column Licrospher ${ }^{\circledR} 100$ RP-18 $(4 \times 4$ mm; $5 \mu$ m packing; Agilent Technologies, Palo Alto, CA, USA). The analysis was carried out as described in Portu et al. [26] with slight modifications to improve peak resolution. For the analysis of anthocyanins, $10 \mu \mathrm{L}$ of previously diluted (1:25) and filtered (Chromafil PET 20/25, Machery-Nagel, Düren, Germany) extract was injected directly into the HPLC and the column was maintained at $40{ }^{\circ} \mathrm{C}$. For the analysis of non-anthocyanin phenolic compounds, previously isolated according to the methodology described by Castillo-Muñoz et al. [27], $10 \mu \mathrm{L}$ of filtered (Chromafil PET 20/25, Machery-Nagel, Düren, Germany) extract was injected into the HPLC. For identification and quantification of compounds, chromatograms were recorded at $280,320,360$, and $520 \mathrm{~nm}$ in the DAD detector. Elution order, retention time (RT), UV/vis spectra, and cross-comparison with available standards and with earlier papers [18] on the polyphenolic composition of the fruit of $V$. meridionale Sw. were used to characterize phenolic compounds in the extract. For quantification, DAD chromatograms were extracted at $520 \mathrm{~nm}$ (anthocyanins), $360 \mathrm{~nm}$ (flavonols), $320 \mathrm{~nm}$ (hydroxybenzoic and hydroxycinnamic acids and stilbenes), and $280 \mathrm{~nm}$ (flavonols), and the calibration curve of the respective standards $\left(R^{2}>0.999\right)$ was used.

\subsection{Sensory Analysis}

The sensory tests for the evaluation of sensory acceptance of patties with different $\mathrm{CBE}$ treatments were conducted in the sensory laboratory of the Meat Technology Centre of Galicia (Ourense, Spain). Tests were held in closed individual booths according to ISO 8589:2010/A1:2014 regulation [28], under white light for the attributes evaluated in raw samples and red light for the attributes evaluated in cooked patties. The sensory sessions were carried out at $1,3,6$, and 9 days of patties elaboration to assess their sensory evolution 
in raw samples. In addition, on day 1, odour, texture, and taste were studied in cooked samples in an oven at $180^{\circ} \mathrm{C}$ until an internal temperature of $70^{\circ} \mathrm{C}$. Samples were offered in disposable plastic dishes presented to the taster coded with a 3-digit number drawn from a table of random numbers [29]. Water and unsalted toasted bread were used at the beginning of sessions and among samples to clean the palate and remove residual flavours. Sensory analysis was conducted with 51 consumers ( 27 females and 24 males aged from 25-40 years), which were selected based on their availability for the evaluation and interest to participate in the research. They were informed about the objectives of the study and the instructions to complete tests by a trained interviewer before starting. The study was approved by the local committee of Centro Tecnológico de la Carne (SEN/2021).

An acceptance test was applied for all treatments to determine how the consumers liked or disliked the patties. At the initial point (day 1), the tasters were asked to evaluate the sensory attributes in either raw patties (appearance and odour) and cooked patties (odour, texture and taste), as well as their overall acceptance using a 7-points hedonic scale ( 1 = I dislike very much and $7=$ I like very much), according to Meilgaard et al. [30]. During shelf life (days 1, 3, 6, and 9), visual attributes acceptance for red colour and surface discolouration were evaluated using a 5-point hedonic scale $(1=$ not acceptable, $5=$ excellent). Thus, either consumer also evaluated the intensity of these attributes using a lineal structured scale from 0 (minimum attribute intensity) to 10 (maximum attribute intensity).

\subsection{Experimental Design and Manufacture of the Pork Patties}

Five batches (15 units per batch, 3 per sampled point) of pork patties were elaborated in the pilot plant of the Meat Technology Centre of Galicia as follows: (i) control without the addition of antioxidant (CON), (ii) control with ascorbic acid (ASC) (500 mg/kg), and three different treatments with CBE with (iii) $250 \mathrm{mg} / \mathrm{kg}$ (CBE250), (iv) $500 \mathrm{mg} / \mathrm{kg}$ (CBE500), and (v) $750 \mathrm{mg} / \mathrm{kg}$ (CBE750). Patties of $80 \mathrm{~g}$ were manufactured using pork lean and backfat from Celta pig breed with an $8 \%$ fat content. Lean and backfat were ground through a mincing plate with an 8-mm diameter in a refrigerated mincer machine (La Minerva, Bologna, Italy). Then, in a vacuum maceration tumbler (Fuerpla, Valencia, Spain), minced lean and backfat were mixed for 3 min with $18 \mathrm{~g}$ of $\mathrm{NaCl}$ per $\mathrm{kg}$, water $(10 \%)$, and ascorbic acid or CBE for each treatment. Meat mass mixed were maintained at $3{ }^{\circ} \mathrm{C}$ for $4 \mathrm{~h}$ and then patties were formed in a burger-maker machine (Gaser, A-2000, Girona, Spain).

Patties were packed in 300-mm thick polystyrene trays, which were sealed with polyethylene film 74-mm thick and permeability of $2 \mathrm{~mL} /\left(\mathrm{m}^{2}\right.$ bar day) suitable for gas mixtures (VIDUCA, Alicante, Spain). The packaging was carried out using a heat sealer LARI3/Pn T-VG-R-SKIN (Ca.Ve.Co., Palazzolo, Italy). The composition of the modified atmosphere was $80 \% \mathrm{O}_{2}-20 \% \mathrm{CO}_{2}$. To simulate supermarket conditions, the trays were stored at $2 \pm 1{ }^{\circ} \mathrm{C}$ under light with lux values (digital lux meter, HT 306, HTC Instruments, Faenza, Italy) in the range of 15-20. The light source was conventional, hence, UV was not filtered.

A characterization of meat mass was carried out before the elaboration of the different patties batches following the methodology described by Pateiro et al. [31]. Briefly, the chemical composition in percentage was as follows: moisture $(70.06 \pm 1.57 \%)$, protein $(18.52 \pm 0.42 \%)$, intramuscular fat $(8.85 \pm 1.71 \%)$, ash $(1.85 \pm 0.10 \%)$, and cholesterol $(24.39 \pm 5.36 \mathrm{mg}$ cholesterol $/ 100 \mathrm{~g}$ pork patty). Concerning fat profile, monounsaturated fatty acids (MUFA) were the predominant ones, with percentages of $54.32 \pm 0.95 \%$, followed by saturated fatty acids (SFA) $(33.80 \pm 1.01 \%)$, and polyunsaturated fatty acids (PUFA) $(11.88 \pm 0.20 \%)$, with oleic acid $(44.70 \pm 0.82 \%)$, palmitic acid $(21.63 \pm 0.58 \%)$, and linoleic acid $(9.34 \pm 0.16 \%)$ being the most predominant fatty acids in MUFA, SFA, and PUFA, respectively. Percentages of n-3 and n-6 fatty acids in the mixture were $0.94 .70 \pm 0.04 \%$ and $10.94 \pm 0.19 \%$, respectively. Lastly, patties were characterized by a cooking loss of $30.47 \pm 1.80 \%$ and a hardness of $120.45 \pm 13.87 \mathrm{~N}$. 


\subsection{Physical Parameters ( $p H$, Colour, and Lipid Oxidation) of the Pork Patties}

Analyses were carried out at 1 (24 h after preparing the patties), 3, 6, and 9 days of storage to determine $\mathrm{pH}$, colour, and lipid oxidation (TBARS). The studied parameters were assessed in triplicate for every sampling point. The $\mathrm{pH}$ of the samples was measured using a digital portable pH-meter (HI 99163, Hanna Instruments, Eibar, Spain), equipped with a penetration probe. Colour parameters were measured using a portable colourimeter (Konica Minolta CM-600d, Osaka, Japan) with pulsed xenon arc lamp, $\mathrm{D}_{65}$ illuminant, $10^{\circ}$ viewing angle geometry, and $8 \mathrm{~mm}$ aperture size, to estimate the colour of the patties in the CIELAB space: lightness $\left(\mathrm{L}^{*}\right)$, redness $\left(\mathrm{a}^{*}\right)$, and yellowness $\left(\mathrm{b}^{*}\right)$. Chroma (saturation index; $C^{*}$ ) and hue $\left(h^{*}\right)$ were calculated following equations provided by American Meat Science Association (AMSA) [32]. For each sample, the colour was measured in three homogeneous different points free of fat. The numerical total colour differences $\left(\Delta \mathrm{E}_{\mathrm{s}}\right.$ and $\left.\Delta \mathrm{E}_{\mathrm{t}}\right)$ [33] were calculated among samples without antioxidant $(\mathrm{CON})$ and treated with the extract (CBE: $250,500$, and 750$)\left(\Delta E_{s}\right)$ and between initial (i: day 1) and final (f: days, 3, 6, and 9) times of storage $\left(\Delta \mathrm{E}_{\mathrm{s}}\right.$ and $\left.\Delta \mathrm{E}_{\mathrm{t}}\right)$, respectively, as follows:

$$
\begin{gathered}
\Delta \mathrm{E}_{\mathrm{s}}=\left[\left(\mathrm{L}_{\mathrm{CBE}}-\mathrm{L}_{\mathrm{CON}}\right)^{2}+\left(\mathrm{a}_{\mathrm{CBE}}-\mathrm{a}_{\mathrm{CON}}\right)^{2}+\left(\mathrm{b}_{\mathrm{CBE}}-\mathrm{b}_{\mathrm{CON}}\right)^{2}\right]^{1 / 2} \\
\Delta \mathrm{E}_{\mathrm{t}}=\left[\left(\mathrm{L}_{\mathrm{f}}-\mathrm{L}_{\mathrm{i}}\right)^{2}+\left(\mathrm{a}_{\mathrm{f}}-\mathrm{a}_{\mathrm{i}}\right)^{2}+\left(\mathrm{b}_{\mathrm{f}}-\mathrm{b}_{\mathrm{i}}\right)^{2}\right]^{1 / 2}
\end{gathered}
$$

Lipid oxidation was evaluated through TBARs index, which was measured using $2 \mathrm{~g}$ of pork patties dispersed in $5 \%$ trichloroacetic acid $(10 \mathrm{~mL})$ and homogenized in an Ultra-Turrax (Ika T25 basic, Staufen, Germany) for $2 \mathrm{~min}$. The homogenate was maintained at $-10{ }^{\circ} \mathrm{C}$ for $10 \mathrm{~min}$ and centrifuged at $2360 \times \mathrm{g}$ for $10 \mathrm{~min}$. The supernatant was filtered through a Whatman $\mathrm{N}^{\circ} 1$ filter paper (GE Healthcare Europe, Barcelona, Spain). Then, $5 \mathrm{~mL}$ of the obtained supernatant was mixed with $0.02 \mathrm{M}$ thiobarbituric acid (TBA) solution $(5 \mathrm{~mL})$ and incubated in a water bath at $96^{\circ} \mathrm{C}$ for $40 \mathrm{~min}$. The absorbance was measured at $532 \mathrm{~nm}$. TBA reactive substances (TBARs) values were calculated from a standard curve of malonaldehyde with 1,1-3,3-tetraethoxypropane (TEP) and expressed as an $\mathrm{mg}$ $\mathrm{MDA} / \mathrm{kg}$ sample.

\subsection{Statistical Analysis}

For the statistical analysis of the results, an analysis of variance (ANOVA) using the general linear model (GLM) was utilized for variables of the study. The least-squares mean (LSM) were separated using Duncan's $t$-test. All statistical tests of LSM were performed for a significance level at $p<0.05$. Correlations between instrumentally measured colour parameters and visual attributes scores $(p<0.05)$ were determined by correlation analyses using Pearson's linear correlation coefficient. Univariate linear regression was performed with the variable with the highest correlation, using the sensorial score as the dependent variable and the selected variable as independent [34]. Statistical analysis was performed using the IBM SPSS Statistics 23.0 program (IBM Corp., New York, NY, USA).

\section{Results}

3.1. Total Phenolic Content (TPC), Total Anthocyanin Content (TAC), and Phenolic Profile of Colombian Berry (V. meridionale Sw.) Extract (CBE)

Table 1 shows the values of total polyphenol (TPC) and total anthocyanin (TAC) values found in the $\mathrm{CBE}$, in the raw material, and the fresh fruit expressed in $\mathrm{mg} / \mathrm{kg}$ of berry. The CBE had a TPC of $83976.25 \pm 167.90 \mathrm{mg} / \mathrm{kg}$, while the raw material and fresh fruit had $3081.60 \pm 6.16 \mathrm{mg} / \mathrm{kg}$ and $1151.65 \pm 2.3 \mathrm{mg} / \mathrm{kg}$, respectively. Concerning TAC, the contents were $29077.50 \pm 747.77 \mathrm{mg} / \mathrm{kg}, 1067.03 \pm 27.44 \mathrm{mg} / \mathrm{kg}$, and $397.7 \pm 10.3 \mathrm{mg} / \mathrm{kg}$ in the same materials. Thus, the anthocyanin compounds account for $35 \%$ of the polyphenolic substances of the CBE. 
Table 1. Total and individual content $(\mathrm{mg} / \mathrm{kg})$ of phenolic compound/subclass identified in Colombian berry (V.meridionale Sw.) methanolic acid extract (MAE), raw material, and fresh fruit.

\begin{tabular}{cccc}
\hline Substance & \multicolumn{3}{c}{ Content (mg/kg of Berry) $\mathbf{~}^{\mathbf{3}}$} \\
\cline { 2 - 4 } & CBE & Raw Material & Fresh Fruit \\
\hline Total polyphenolic & $83,976.25 \pm 167.90$ & $3081.60 \pm 6.16$ & $1151.65 \pm 2.30$ \\
Total anthocyanin & $29,077.50 \pm 747.77$ & $1067.03 \pm 27.44$ & $398.77 \pm 10.30$ \\
\hline Cyanidin derivatives & Individual polyphenolic compounds & $106 \pm 0.70$ \\
Quercetin-3-glucuronide & $7729.38 \pm 52.15$ & $283.64 \pm 1.90$ & $13.47 \pm 0.20$ \\
Quercetin-3-glucoside & $982.50 \pm 11.30$ & $36.05 \pm 0.40$ & $0.91 \pm 0.0$ \\
Syringic acid & $66.50 \pm 3.20$ & $2.44 \pm 0.10$ & $0.82 \pm 0.0$ \\
p-Coumaric acid & $60.13 \pm 1.59$ & $2.21 \pm 0.0$ & $0.52 \pm 0.0$ \\
$\Sigma$ Kaempferol derivatives & $37.96 \pm 1.78$ & $1.39 \pm 0.0$ & $61.17 \pm 0.6$ \\
(3-glucoside + rutinoside) & $4460.13 \pm 44.7$ & $163.67 \pm 1.6$ & \\
\hline
\end{tabular}

${ }^{1}$ Results are expressed as mean \pm SD. CBE: Colombian berry extract.

From the anthocyanidins profile of CBE investigated (Figure 1), the most abundant anthocyanidin were the cyanidin derivatives $(7729.38 \pm 52.15 \mathrm{mg} / \mathrm{kg}$ CBE$)$. This amount represents $27 \%$ of the total anthocyanins contained in the extract. The HPLC profile of flavanol compounds (Figure 1b) indicated the presence of quercetin (glucuronide and glucoside) and kaempferol (glucoside and rutinoside) as the most abundant compounds of this family. The amount of glucuronide formed in the CBE $(982.50 \pm 11.30 \mathrm{mg} / \mathrm{kg})$ was higher than that found for glucoside $(66.50 \pm 3.20 \mathrm{mg} / \mathrm{kg}$ CBE). The kaempferol compounds reached the means values of $4460.13,163.67$, and $61.67 \mathrm{mg} / \mathrm{kg}$ in the CBE, raw material, and fresh fruit, respectively. Concerning the non-flavonoids compounds, phenolic acids were also identified and quantified. The sum of the content of hydroxycinnamic acids (syringic and p-coumaric) was $98.09,4.50$, and $1.34 \mathrm{mg} / \mathrm{kg}$ in the $\mathrm{CBE}$, raw material, and fresh fruit, respectively.
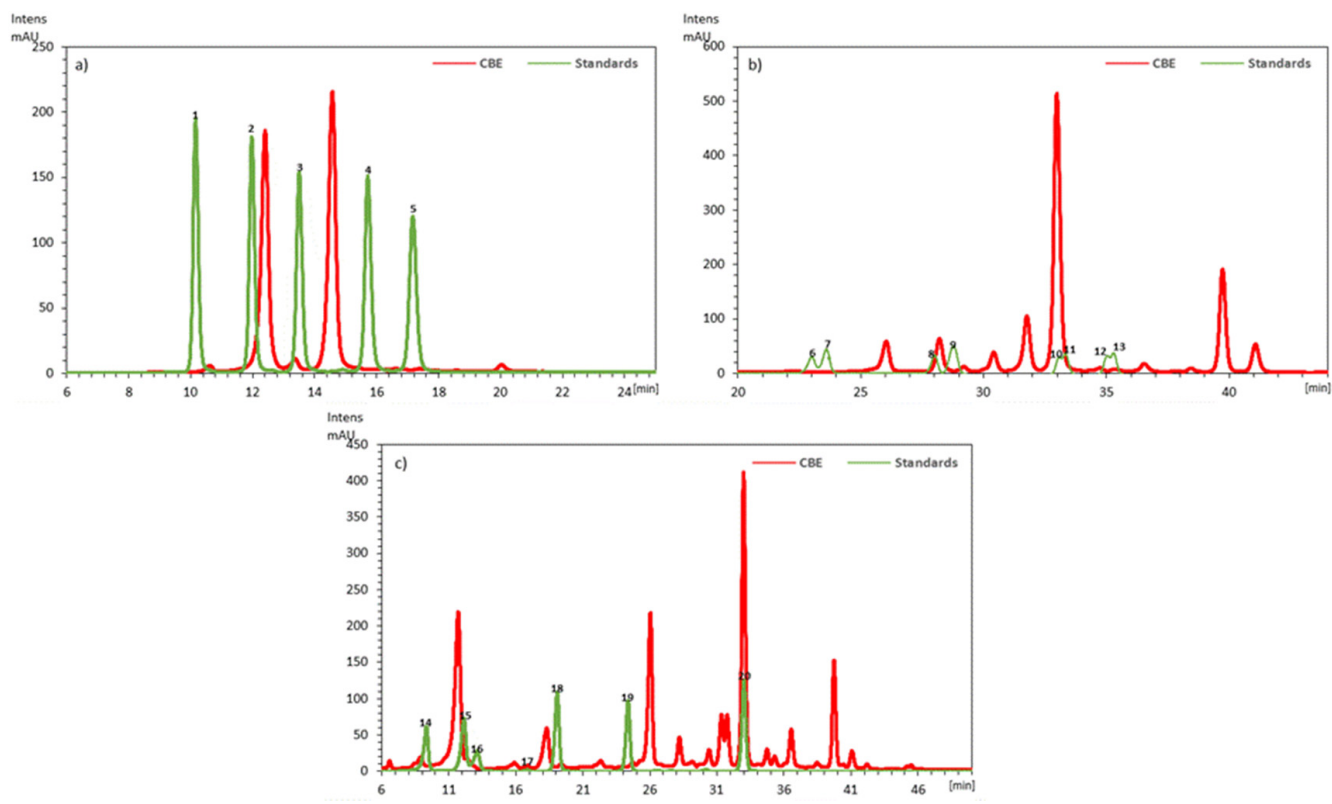

Figure 1. Expanded DAD-chromatograms of CBE and standards for (a) anthocyanins (detection at $520 \mathrm{~nm}$ ), (b) flavonols (detection at $360 \mathrm{~nm}$ ), and (c) phenolic acids and stilbenes (detection at $320 \mathrm{~nm}$ ). (1) Delphinidin-3-glucoside; (2) cyanidin3-glucoside; (3) petunidin-3-glucoside; (4) peonidin-3-glucoside; (5) malvidin-3-glucoside; (6) myricetin-3-glucoside; (7) myricetin-3-glalactoside; (8) quercetin-3-glucoside; (9) quercetin-3-glucuronide; (10) kaempherol-3-glucoside; (11) kaempherol-3-rutinoside; (12) isorhamnetin-3-glucoside; (13) isorhamnetin-3-rutinoside; (14) $t$-coumaric acid; (15) caffeic acid; (16) syringic acid; (17) fertaric acid; (18) $p$-coumaric acid; (19) ferulic acid; and (20) $t$-resveratrol. 


\subsection{Antioxidant Activity of Colombian Berry (V. meridionale Sw.) Extract ( $C B E)$}

The in vitro antioxidant activity of the CBE was evaluated before adding it to pork patties. Results for the four in vitro tests (DPPH, ABTS ${ }^{\bullet+}$, ORAC, and FRAP), as well as the $\mathrm{IC}_{50}$ using the $\mathrm{DPPH}$ procedure, are shown in Table 2.

Table 2. In vitro antioxidant activity of Colombian berry (V. meridionale Sw.) extract.

\begin{tabular}{ccccc}
\hline DPPH $^{1, *}$ & IC $_{50}{ }^{2, *}$ & ABTS $^{\bullet+3, *}$ & ORAC $^{\mathbf{}^{* * *}}$ & FRAP $^{5, *}$ \\
\hline $143.68 \pm 3.87$ & $1.55 \pm 0.01$ & $253.27 \pm 12.57$ & $472.25 \pm 6.08$ & $1.98 \pm 0.02$ \\
\hline
\end{tabular}

${ }^{1} \mu \mathrm{g}$ trolox $/ \mathrm{g},{ }^{2} \mathrm{mg} / \mathrm{mL},{ }^{3} \mathrm{~g}$ ascorbic acid $/ \mathrm{kg},{ }^{4} \mathrm{mg} \mathrm{TE} / \mathrm{g},{ }^{5} \mathrm{~mol}$ ferric sulphate $/ \mathrm{kg} .{ }^{*}$ Results are expressed as mean \pm SD. 1,1-diphenyl-2-picrylhydrazyl (DPPH) radical scavenging capacity, half maximal inhibitory antioxidant concentration $\left(\mathrm{IC}_{50}\right), 2,2^{\prime}$-azino-bis-3-ethylbenzothiazoline-6-sulfonic acid (ABTS), ferric reducing antioxidant power assay (FRAP) and oxygen radical absorbance capacity (ORAC).

\subsection{Evaluation of $\mathrm{pH}$ and Colour of Pork Patties during Storage}

The effect of the $\mathrm{CBE}$ treatment on the $\mathrm{pH}$ values, instrumentally measured colour parameters $\left(\mathrm{L}^{*}, \mathrm{a}^{*}, \mathrm{~b}^{*}\right), \mathrm{C}^{*}, \mathrm{~h}^{*}$, and $\Delta \mathrm{E}_{\mathrm{s}}$ during the shelf life of patties is summarized in Table 3. The addition of CBE had a significant $(p<0.05)$ effect on the $\mathrm{pH}$ and colour values of the patties, except for $\mathrm{a}^{*}$ and $\mathrm{C}^{*}$ on day 3 (among treatments), $\mathrm{b}^{*}$ during storage (CON, ASC, and CBE250 treatments), and $\Delta \mathrm{E}_{\mathrm{s}}$ on days 1,3 , and 6 (among treatments). The highest $(p \leq 0.001) \mathrm{pH}$ values were observed in CBE500 and CBE750 in comparison to the other batches (CON, ASC, and CBE250) at the beginning of the experiment (day 1). Afterwards, the $\mathrm{pH}$ values of all treatments decreased $(p \leq 0.001)$ with the storage until the sixth day with a slight increase $(p \leq 0.001)$ on the ninth day (except for ASC and CBE750). Indeed, for CBE500 no differences in $\mathrm{pH}$ between days 1 and 9 were observed.

Table 3. Effect of the treatments in the $\mathrm{pH}$ and colour parameters $\left(\mathrm{L}^{*}, \mathrm{a}^{*}, \mathrm{~b}^{*}, \mathrm{C}^{*}, \mathrm{~h}^{*}\right.$, and $\left.\Delta \mathrm{E}_{\mathrm{s}}\right)$ of the pork patties during storage.

\begin{tabular}{|c|c|c|c|c|c|c|c|c|}
\hline \multirow{2}{*}{ Parameters } & \multirow{2}{*}{ Day } & \multicolumn{5}{|c|}{ Treatments } & \multirow{2}{*}{ SEM } & \multirow{2}{*}{$p$-Value } \\
\hline & & $\mathrm{CON}$ & ASC & CBE250 & CBE500 & CBE750 & & \\
\hline \multirow{4}{*}{$\mathrm{pH}$} & 1 & $5.58^{a, B}$ & $5.57^{\mathrm{a}, \mathrm{B}}$ & $5.57^{\mathrm{a}, \mathrm{B}}$ & $5.67^{\mathrm{a}, \mathrm{A}}$ & $5.68^{\mathrm{a}, \mathrm{A}}$ & 0.014 & $<0.001$ \\
\hline & 3 & $5.46^{\mathrm{b}, \mathrm{D}}$ & $5.53^{b, B, C}$ & $5.54^{\mathrm{a}, \mathrm{A}, \mathrm{B}}$ & $5.49^{c, C, D}$ & $5.57^{\mathrm{b}, \mathrm{A}}$ & 0.012 & 0.002 \\
\hline & 6 & $5.32^{c, C}$ & $5.41^{\mathrm{c}, \mathrm{A}, \mathrm{B}}$ & $5.37^{\mathrm{c}, \mathrm{B}, \mathrm{C}}$ & $5.42^{\mathrm{d}, \mathrm{A}, \mathrm{B}}$ & $5.47^{\mathrm{c}, \mathrm{A}}$ & 0.016 & 0.014 \\
\hline & 9 & $5.49^{\mathrm{b}, \mathrm{B}}$ & $5.42^{\mathrm{c}, \mathrm{C}}$ & $5.43^{b, C}$ & $5.61^{\mathrm{b}, \mathrm{A}}$ & $5.53^{b, c, B}$ & 0.020 & $<0.001$ \\
\hline \multirow{2}{*}{$\begin{array}{c}\text { SEM } \\
p \text {-value }\end{array}$} & & 0.029 & 0.022 & 0.025 & 0.030 & 0.026 & & \\
\hline & & $<0.001$ & $<0.001$ & $<0.001$ & $<0.001$ & 0.002 & & \\
\hline \multirow{4}{*}{$\mathrm{L}^{*}$} & 1 & $48.90^{\mathrm{b}, \mathrm{A}}$ & $46.93^{b, A, B}$ & $43.32^{\mathrm{c}, \mathrm{B}, \mathrm{C}}$ & $42.96^{c, C}$ & $39.75^{b, c}$ & 0.963 & 0.002 \\
\hline & 3 & $46.84^{\mathrm{b}, \mathrm{A}}$ & $48.06^{\mathrm{b}, \mathrm{A}}$ & $46.81^{\mathrm{b}, \mathrm{A}}$ & $42.69^{c, B}$ & $42.28^{\mathrm{a}, \mathrm{b}, \mathrm{B}}$ & 0.694 & 0.001 \\
\hline & 6 & $53.98^{\mathrm{a}, \mathrm{A}}$ & $50.34^{\mathrm{b}, \mathrm{B}}$ & $48.15^{\mathrm{b}, \mathrm{B}, \mathrm{C}}$ & $45.30^{b, C, D}$ & $42.15^{\mathrm{a}, \mathrm{b}, \mathrm{D}}$ & 1.156 & $<0.001$ \\
\hline & 9 & $55.75^{\mathrm{a}, \mathrm{A}}$ & $55.50^{\mathrm{a}, \mathrm{A}}$ & $54.18^{\mathrm{a}, \mathrm{A}}$ & $49.40^{\mathrm{a}, \mathrm{B}}$ & $44.86^{\mathrm{a}, \mathrm{C}}$ & 1.158 & $<0.001$ \\
\hline \multirow{2}{*}{$\begin{array}{c}\text { SEM } \\
p \text {-value }\end{array}$} & & 1.264 & 1.084 & 1.204 & 0.821 & 0.648 & & \\
\hline & & 0.009 & 0.002 & $<0.001$ & $<0.001$ & 0.016 & & \\
\hline \multirow{4}{*}{$a^{*}$} & 1 & $14.45^{\mathrm{a}, \mathrm{A}, \mathrm{B}}$ & $11.76^{\mathrm{a}, \mathrm{C}}$ & $13.13^{\mathrm{a}, \mathrm{B}, \mathrm{C}}$ & $13.25^{\mathrm{b}, \mathrm{B}, \mathrm{C}}$ & $15.67^{\mathrm{a}, \mathrm{A}}$ & 0.433 & 0.019 \\
\hline & 3 & $13.59^{\mathrm{a}}$ & $13.08^{a}$ & $13.20^{\mathrm{a}}$ & $15.20^{\mathrm{a}}$ & $13.55^{b}$ & 0.284 & 0.095 \\
\hline & 6 & $4.42^{b, C}$ & $8.25^{b, A, B}$ & $7.58^{b, B}$ & $8.67^{\mathrm{c}, \mathrm{A}, \mathrm{B}}$ & $9.06^{\mathrm{c}, \mathrm{A}}$ & 0.466 & $<0.001$ \\
\hline & 9 & $2.03^{c, B}$ & 2.69 c,B & $2.42^{c, B}$ & $3.85^{\mathrm{d}, \mathrm{A}}$ & $4.44^{\mathrm{d}, \mathrm{A}}$ & 0.261 & $<0.001$ \\
\hline \multirow{2}{*}{$\begin{array}{c}\text { SEM } \\
p \text {-value }\end{array}$} & & 1.678 & 1.227 & 1.359 & 1.328 & 1.316 & & \\
\hline & & $<0.001$ & $<0.001$ & $<0.001$ & $<0.001$ & $<0.001$ & & \\
\hline \multirow{4}{*}{$b^{*}$} & 1 & $18.65^{\mathrm{A}}$ & $16.47^{\text {B }}$ & $15.78^{B, C}$ & $14.61^{b, C, D}$ & $14.30^{\mathrm{a}, \mathrm{D}}$ & 0.444 & $<0.001$ \\
\hline & 3 & $17.39 \mathrm{~A}$ & $17.10^{\mathrm{A}, \mathrm{B}}$ & $16.28^{\mathrm{A}, \mathrm{B}}$ & $15.60^{\mathrm{a}, \mathrm{B}}$ & $13.60^{b, c}$ & 0.402 & 0.001 \\
\hline & 6 & $17.21^{\mathrm{A}}$ & $16.69^{\mathrm{A}}$ & $14.79^{\mathrm{B}}$ & $14.29 \mathrm{~b}, \mathrm{~B}$ & $12.57^{\mathrm{c}, \mathrm{C}}$ & 0.463 & $<0.001$ \\
\hline & 9 & $18.12^{\mathrm{A}}$ & $16.24^{\mathrm{B}}$ & $16.75^{\mathrm{A}, \mathrm{B}}$ & $16.08^{\mathrm{a}, \mathrm{B}}$ & $14.21^{\mathrm{a}, \mathrm{b}, \mathrm{C}}$ & 0.386 & 0.004 \\
\hline SEM & & 0.289 & 0.233 & 0.305 & 0.250 & 0.222 & & \\
\hline$p$-value & & 0.288 & 0.662 & 0.105 & 0.007 & 0.001 & & \\
\hline
\end{tabular}


Table 3. Cont.

\begin{tabular}{|c|c|c|c|c|c|c|c|c|}
\hline \multirow{2}{*}{ Parameters } & \multirow{2}{*}{ Day } & \multicolumn{5}{|c|}{ Treatments } & \multirow{2}{*}{ SEM } & \multirow{2}{*}{$p$-Value } \\
\hline & & $\mathrm{CON}$ & ASC & CBE250 & CBE500 & CBE750 & & \\
\hline \multirow{4}{*}{$C^{*}$} & 1 & $23.63^{\mathrm{a}, \mathrm{A}}$ & $20.25^{\mathrm{a}, \mathrm{b}, \mathrm{B}}$ & $20.53^{a, B}$ & $19.73^{b, B}$ & $21.21^{\mathrm{a}, \mathrm{B}}$ & 0.431 & 0.008 \\
\hline & 3 & $22.08^{a}$ & $21.53^{\mathrm{a}}$ & $20.96^{\mathrm{a}}$ & $21.78^{a}$ & $19.20^{b}$ & 0.363 & 0.058 \\
\hline & 6 & $17.77^{\mathrm{b}, \mathrm{A}}$ & $18.62^{\mathrm{b}, \mathrm{A}}$ & $16.64^{\mathrm{b}, \mathrm{B}}$ & $16.72^{\mathrm{c}, \mathrm{B}}$ & $15.50^{c, C}$ & 0.304 & $<0.001$ \\
\hline & 9 & $18.23^{b, A}$ & $16.46^{\mathrm{c}, \mathrm{B}, \mathrm{C}}$ & $16.93^{b, A, B}$ & $16.54^{\mathrm{c}, \mathrm{B}, \mathrm{C}}$ & $14.89^{\mathrm{c}, \mathrm{C}}$ & 0.343 & 0.012 \\
\hline \multirow{2}{*}{$\begin{array}{c}\text { SEM } \\
p \text {-value }\end{array}$} & & 0.814 & 0.621 & 0.641 & 0.674 & 0.801 & & \\
\hline & & 0.001 & 0.001 & 0.001 & $<0.001$ & $<0.001$ & & \\
\hline \multirow{4}{*}{$\mathrm{h}^{*}$} & 1 & $52.40^{\mathrm{c}, \mathrm{A}}$ & $54.38^{\mathrm{c}, \mathrm{A}}$ & $50.24^{\mathrm{c}, \mathrm{A}, \mathrm{B}}$ & $47.78^{\mathrm{c}, \mathrm{B}}$ & $42.40^{c, C}$ & 1.207 & $<0.001$ \\
\hline & 3 & $51.96^{\mathrm{c}, \mathrm{A}}$ & $52.64^{\mathrm{c}, \mathrm{A}}$ & $50.96^{\mathrm{c}, \mathrm{A}}$ & $45.76^{\mathrm{c}, \mathrm{B}}$ & $45.13^{\mathrm{c}, \mathrm{B}}$ & 0.909 & $<0.001$ \\
\hline & 6 & $75.56^{\mathrm{b}, \mathrm{A}}$ & $63.71^{b, B}$ & $62.85^{b, B, C}$ & $58.75^{b, C}$ & $54.21^{\mathrm{b}, \mathrm{D}}$ & 1.967 & $<0.001$ \\
\hline & 9 & $83.60^{a, A}$ & $80.59^{a, B}$ & $81.74^{\mathrm{a}, \mathrm{A}, \mathrm{B}}$ & $76.53^{a, C}$ & $72.69^{a, D}$ & 1.100 & $<0.001$ \\
\hline \multirow{2}{*}{$\begin{array}{c}\text { SEM } \\
p \text {-value }\end{array}$} & & 4.254 & 3.370 & 3.874 & 3.692 & 3.607 & & \\
\hline & & $<0.001$ & $<0.001$ & $<0.001$ & $<0.001$ & $<0.001$ & & \\
\hline \multirow{4}{*}{$\Delta \mathrm{E}_{\mathrm{s}}$} & 1 & & & 6.590 & 7.633 & 10.360 & 0.960 & 0.284 \\
\hline & 3 & & & 2.9800 & 4.9100 & 6.0400 & 0.698 & 0.206 \\
\hline & 6 & & & 7.147 & 10.230 & 13.557 & 1.212 & 0.072 \\
\hline & 9 & & & $2.490^{\mathrm{C}}$ & $7.013^{B}$ & $11.837^{\mathrm{A}}$ & 1.452 & 0.003 \\
\hline
\end{tabular}

CON: control, ASC: ascorbic; CBE250: Colombian berry extract 250 ppm, CBE500: Colombian berry extract 500 ppm, CBE750: Colombian berry extract $750 \mathrm{ppm}$. SEM: Standard error mean. Values with different letters (A-D) in the same row are significantly different $(p<0.05)$; values with different letters $(\mathrm{a}-\mathrm{d})$ in the same column are significantly different $(p<0.05)$.

Concerning colour parameters, at the beginning of the storage (day 1), CBE500 and CBE750 treatments showed the lowest $(p \leq 0.01) \mathrm{L}^{*}$, while CBE750 had the higher $(p<0.05) \mathrm{a}^{*}$, lower $(p<0.001) \mathrm{b}^{*}$, and lower $(p \leq 0.001) \mathrm{h}^{*}$. On the other hand, at the end of the storage, the CBE750 treatment presented the lowest $\mathrm{L}^{*}(\mathrm{CBE750}<\mathrm{CBE500}<\mathrm{CB} 250$, $A S C$, and CON) and $b^{*}$, and the highest $\triangle \mathrm{E}_{\mathrm{S}}(\mathrm{CBE750}>\mathrm{CBE} 500>\mathrm{CB} 250)$. However, despite the extract addition affecting $(p<0.05)$ the patties colour parameters, no significant differences for $\mathrm{L}^{*}, \mathrm{a}^{*}, \mathrm{~b}^{*}, \mathrm{C}^{*}$, and $\mathrm{h}^{*}$ were observed between CBE250 and CON at day 9.

The $\mathrm{a}^{*}$ parameters of patties were in the range of 11.76 (ASC) to 15.67 (CBE750) at the beginning of the storage (day 1$)$, showing a significant $(p \leq 0.001)$ redness decrease at the end of the studied storage (day 9), with values in the range between $2.03(\mathrm{CON})$ and 4.44 (CBE750). As seen from Table 3, despite CON and CBE750 batches presenting no significant $(p \geq 0.05)$ differences in $\mathrm{a}^{*}$ at day 1 , the highest $\mathrm{a}^{*}$ values at day 9 were detected in patties with the higher CBE content (CB 500 and CBE750).

Concerning the $\triangle E$ s parameter, which indicates the numerical difference among the $\mathrm{CON}$ batch and the experimental batches in terms of colour, the values for CBE250, CBE500, and CBE750 until day 6 were in the range between 8.19 (day 1) and 10.3 (day 6), and without significant differences. On the contrary, on day 9, the three $\mathrm{CBE}$ batches showed significant $(p \leq 0.01)$ differences among treatments (CBE750 > CBE500 > CBE250), reaching the CBE750 batch the highest $\triangle \mathrm{Es}$ value.

\subsection{Evaluation of Lipid Oxidation (TBARS) and $\Delta E_{t}$ of Pork Patties during Storage}

The results for lipid oxidation and $\Delta \mathrm{E}_{\mathrm{t}}$ during storage are shown in Figure 2. At the beginning (day 1), TBARS values ranged from $0.10 \mathrm{mg} \mathrm{MDA} / \mathrm{kg}$ (CBE250) to $0.29 \mathrm{MDA} / \mathrm{kg}$ $(\mathrm{CON})$, with significant $(p \leq 0.01)$ differences comparing the control with the other batches (CON > ASC, CBE250, CBE500, CBE750). No significant $(p \geq 0.05)$ differences were observed when comparing batches ASC vs. CBE250 and CBE500 at the beginning (day 1; 0.13 vs. 0.10 and $0.14 \mathrm{MDA} / \mathrm{kg}$, respectively) and at the end (day 9; 5.22 vs. 4.53 and $4.78 \mathrm{MDA} / \mathrm{kg}$, respectively) of the storage time. However, the trend showed that, as the days of the storage progressed (days 3 and 6), the patties with the lowest TBARS values were those elaborated with CBE. Moreover, at the end of the refrigerated period, the CBE750 batch displayed the lowest $(p \leq 0.001)$ TBARS value $(2.27 \mathrm{MDA} / \mathrm{kg}$; Figure 2a). 

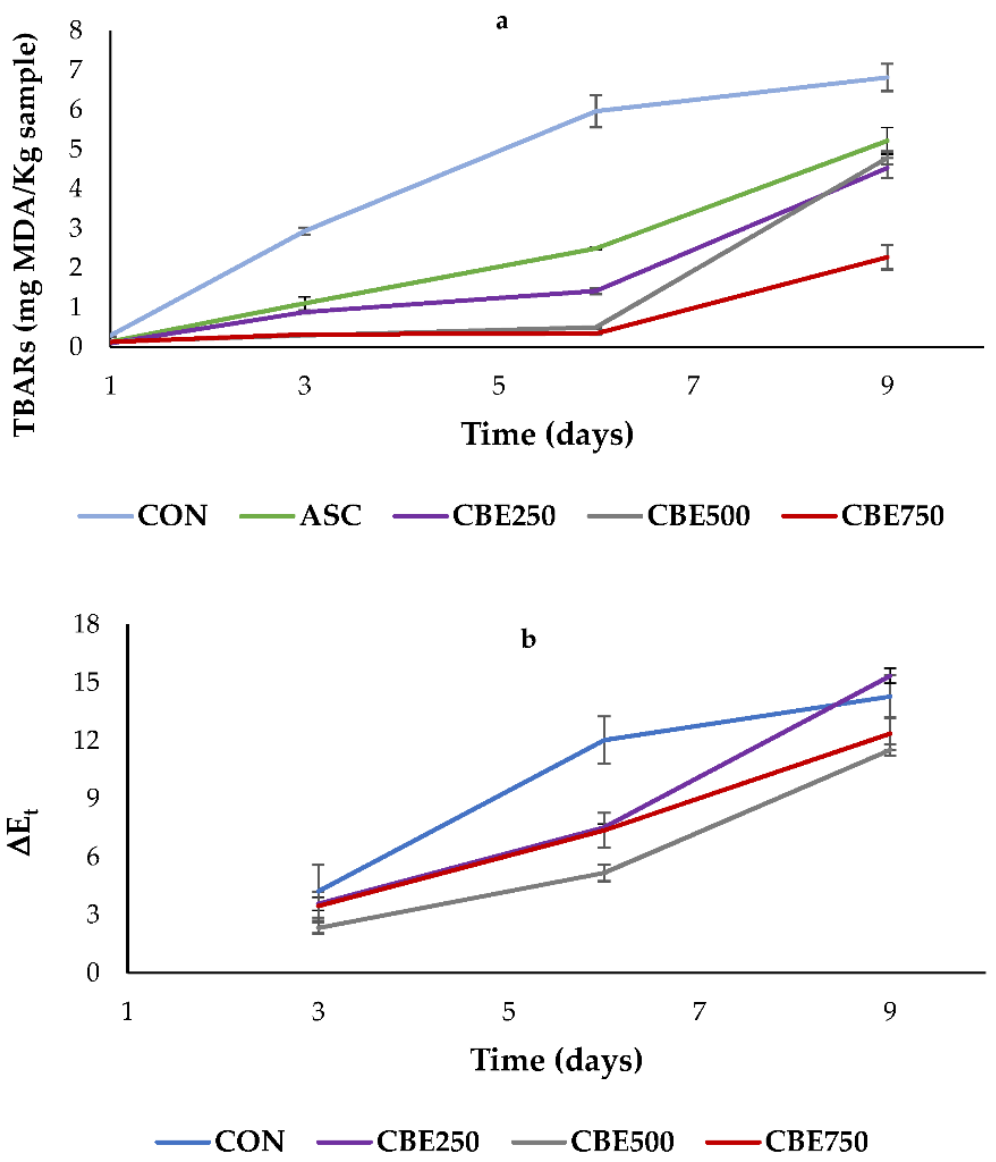

Figure 2. (a) TBARS and (b) $\Delta \mathrm{E}_{\mathrm{t}}$ values of pork patties during refrigerated storage. Pork patties without antioxidant (CON), treated with ascorbic acid (ASC), and treated with different levels of Colombian berry extract (CBE) (CBE250: 250 ppm; CBE500: 500 ppm; CBE750: 750 ppm).

It is well-known that lipid oxidation and plant extracts could modify the colour of the patties, hence the total colour difference $\left(\Delta E_{t}\right)$ between days ( 1 vs. 3, 1 vs. 6, and 1 vs. 9) for four batches (CON, CBE250, CBE500, and CBE750) was calculated. Only significant $(p \leq 0.01)$ differences were observed on day 1 vs. 6 (CON > CBE250, CBE500, and CBE750). On the other hand, colour change considering days 1 vs. 3 and 1 vs. 9 was similar $(p \geq 0.05)$ among samples, indicating an attenuation of the colour modification promoted by CBE treatment at the beginning and the end of the experiment. In addition, in the present study, a positive Pearson's correlation was found between TBARS values with $L^{*}\left(R^{2}=0.6831\right.$, $p<0.001 ; n=60)$ and $h^{*}\left(R^{2}=0.7833, p<0.001 ; n=60\right)$ and negative between TBARS and $\mathrm{a}^{*}\left(R^{2}=0.6770, p<0.001 ; n=60\right)$.

\subsection{Sensory Analysis}

\subsubsection{Sensory Acceptance}

To determine if the CBE could affect the sensorial characteristics of the pork patties, an acceptance test was conducted (Figure 3). From the test performed, the raw patties showed a significant difference only for appearance $(p \leq 0.01)$, while cooked patties displayed significant differences for odour $(p<0.05)$ and taste $(p \leq 0.01)$. All treatments received an overall liking score between 4.2 and 5.4 (acceptability limit of 3 ) with no significant $(p \geq 0.05)$ differences among batches, indicating that the addition of CBE did not alter the patties' acceptability. Therefore, CBE could be used as an ingredient in pork patties without impairing the sensory characteristics of the product. 


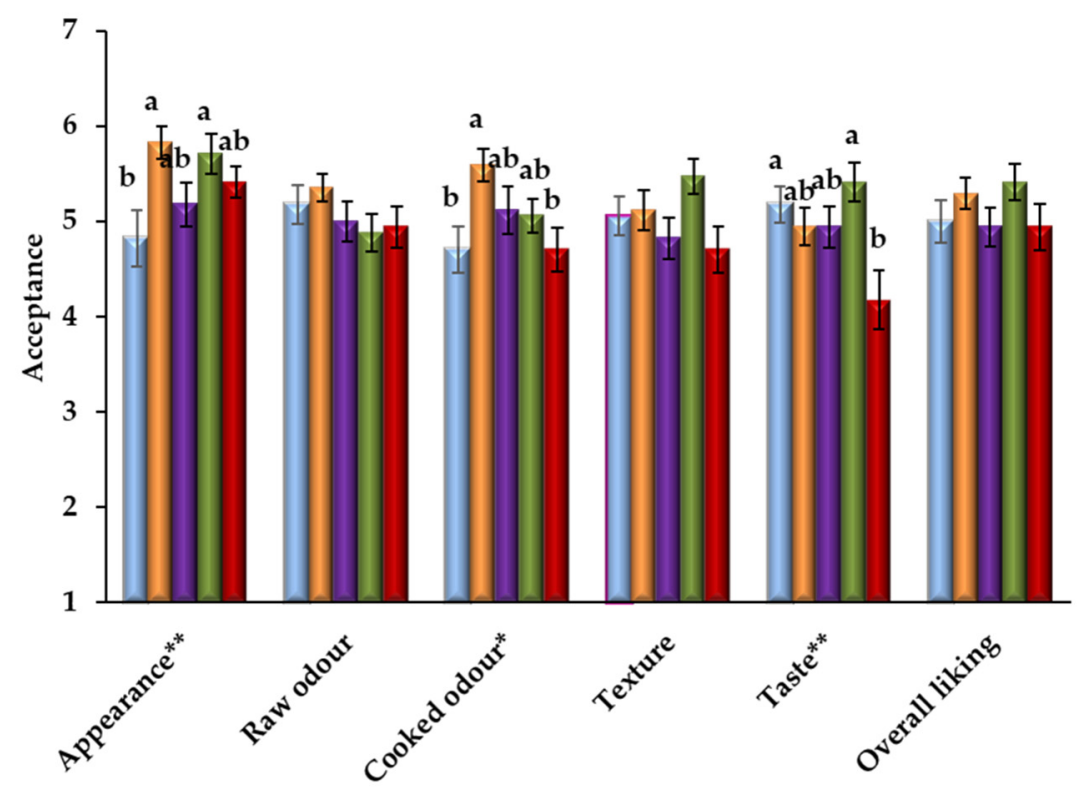

Figure 3. Sensory scores of acceptances attributed by the consumers on day 1 for raw and cooked patties produced without antioxidant (CON), with ascorbic acid (ASC), and with Colombian berry extract (CBE250: 250 ppm; CBE500: 500 ppm; CBE750: 750 ppm). Hedonic scale in either raw patties (appearance and odour) and cooked burgers (odour, texture, and taste), and their overall liking using a 7 -points hedonic scale $(1=\mathrm{I}$ dislike very much and $7=\mathrm{I}$ like very much). Mean values (corresponding to the same parameter) followed by a different letter (a-b) differ significantly $(p<0.05$; Tukey's test). ${ }^{*} p<0.5 ;{ }^{* *} p<0.01$. Error bars corresponding to standard error.

3.5.2. Visual Attributes Evaluation during Shelf-Life: Red Colour Intensity (RCI) and Surface Discolouration Intensity (SDI)

The appearance of the pork patties, assessed visually during the 9 days of storage, is represented in Figure 4. Regarding the evolution of the sensory properties, the addition of $\mathrm{CBE}$ affected the colour at day 1 and during the storage period.

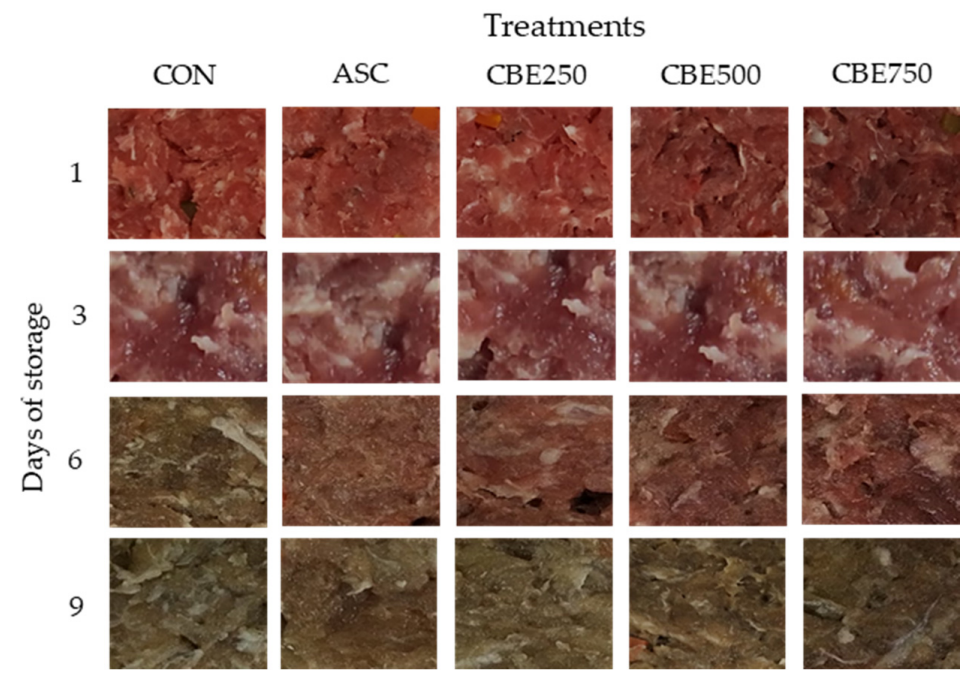

Figure 4. Photographs of pork patties without antioxidant (CON), treated with ascorbic acid (ASC) and treated with different levels of Colombian berry extract (CBE) (CBE250: 250 ppm; CBE500: 500 ppm; CBE750: 750 ppm) in each day of evaluation. 
For the analysis of RCI undertaken on the raw patties (Figure 5a), panellists attributed the lower values for CON (6.6) and ASC (5.8) on day 1, while the higher scores were obtained for patties elaborated with Colombian berry extract (CBE250, CBE500, and CBE750; $7.6,9.5$, and 9.4, respectively). On the contrary, only patties with the higher extract amount (CBE500 and CBE750) maintained a higher intensity of red colour until day 6 (RCI $\geq 7.7)$. For the same period (day 6) CON, ASC, and CBE250 batches received 0.0, 3.7, and 4.8, respectively. Conversely, concerning the hedonic scale, all treatments had similar acceptance values $(4.2-4.6)$ on day 3 , meanwhile all batches were considered unacceptable $(\mathrm{RCI}<3)$ on day 6.
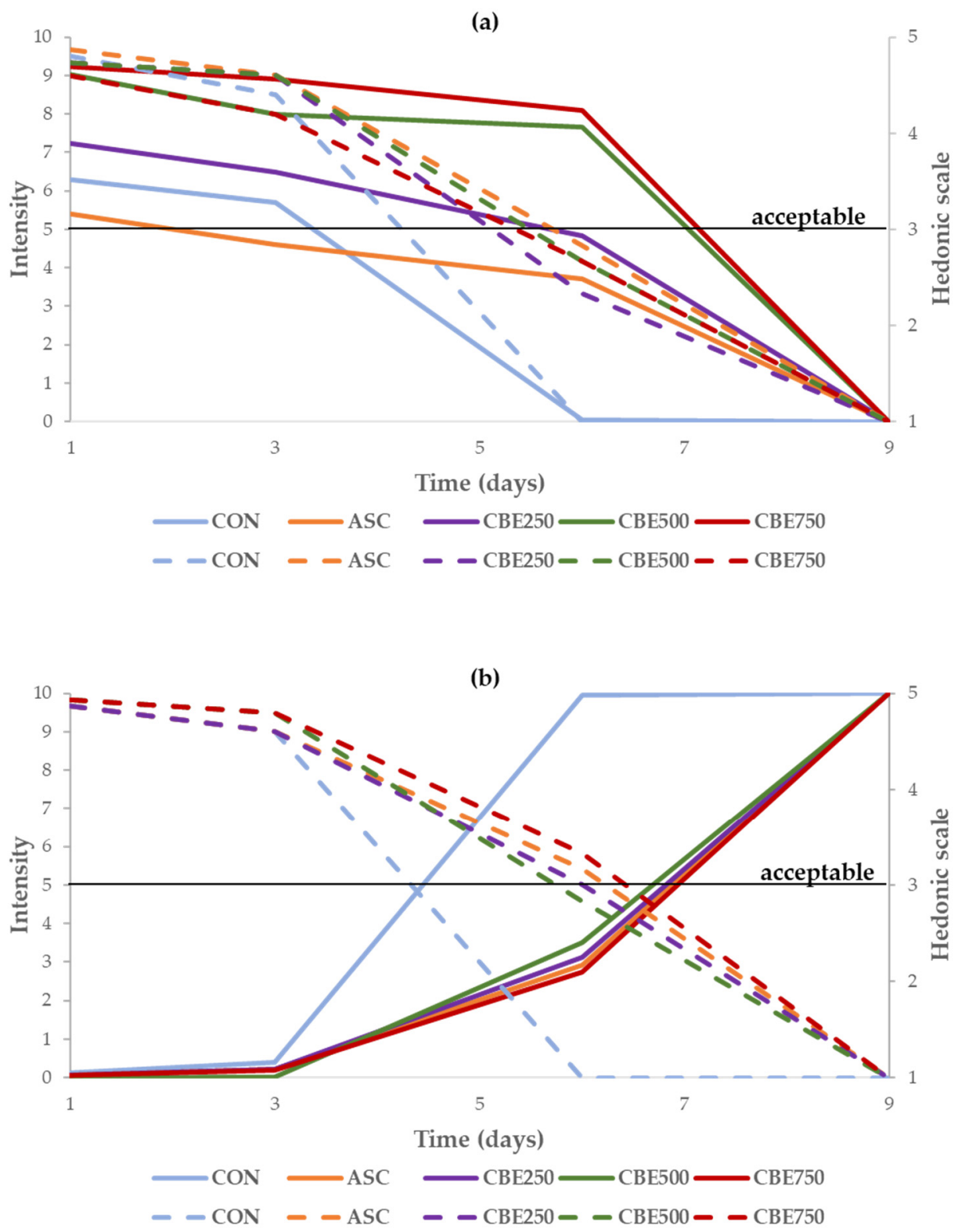

Figure 5. Visual attributes (a) red colour and (b) surface discolouration evaluated by the consumers during shelf-life (days 1, 3, 6, and 9) for raw patties. CON: without antioxidant; ASC: with ascorbic acid; CBE250: 250 ppm of Colombian berry extract; CBE500: 500 ppm of Colombian berry extract; CBE750: $750 \mathrm{ppm}$ of Colombian berry extract. Intensity of the attributes was evaluated using a linear structured scale from 0 (minimum attribute intensity) to 10 (maximum attribute intensity). Acceptance was evaluated using a five-point hedonic scale ( $1=$ not acceptable, $5=$ excellent $)$. 
Concerning SDI (Figure 5b), all treatments received similar evaluation (0.0-0.4) by consumers until day 3 . In addition, on day 6 , except for CON (SDI $=10)$, all treatments were evaluated with lower values for discolouration (SDI $\leq 3.5)$. Regarding the hedonic scale, CON and CBE500 treatments were already unacceptable (SDI $<3$ ) on day 6 , while ASC, CBE250, and CBE750 were still considered acceptable during this period.

\subsubsection{Correlations between Colour Parameters and Visual Attributes of Pork Patties}

Given that the red colour parameters during the shelf life of pork patties were extended mostly in the CBE treatment (CBE500 and CBE750 batches showed the higher $\mathrm{a}^{*}$ values at day 9), it is interesting to correlate sensory (visual colour assessment scores) and instrumental parameters for these data. Pearson's correlation coefficients obtained for instrumentally measured colour parameters $\left(\mathrm{L}^{*}, \mathrm{C}^{*}\right.$, and $\left.\mathrm{h}^{*}\right)$ and those from the sensory analysis for visual attributes RCI, SDI, and red colour acceptance (RCA) are presented in Table 4. Regression analysis showed that the correlations were significant $(p \leq 0.001)$ and strong regardless of $\mathrm{h}^{*}$ and RCI $(-0.947)$, SDI (0.958), and RCA $(-0.932)$.

Table 4. Correlations between instrumental colour parameters $\left(\mathrm{L}^{*}, \mathrm{C}^{*}\right.$, and $\left.\mathrm{h}^{*}\right)$ and the visual attributes (red colour intensity, surface discolouration intensity, and red colour acceptance) were evaluated by panellists in sensory analysis of pork patties.

\begin{tabular}{ccccccc}
\hline & $\mathbf{L}^{*}$ & $\mathbf{C}^{*}$ & $\mathbf{h}^{*}$ & $\mathbf{R C I}$ & $\mathrm{SDI}$ & $\mathbf{R C A}$ \\
\hline $\mathrm{L}^{*}$ & 1 & -0.264 & $0.851^{* * *}$ & $-0.839^{* * *}$ & $0.707^{* * *}$ & $-0.660^{* * *}$ \\
$\mathrm{C}^{*}$ & & 1 & $-0.662^{* *}$ & $0.522^{* *}$ & $-0.735^{* * *}$ & $0.837^{* * *}$ \\
$\mathrm{~h}^{*}$ & & & 1 & $-0.947^{* * *}$ & $0.958^{* * *}$ & $-0.932^{* * *}$ \\
$\mathrm{RCI}$ & & & & 1 & $-0.909^{* * *}$ & $0.851^{* * *}$ \\
SDI & & & & & 1 & $-0.967^{* * *}$ \\
RCA & & & & & & 1 \\
\hline
\end{tabular}

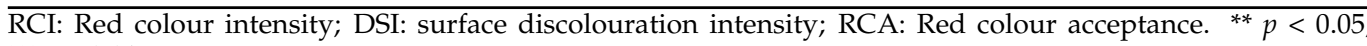
*** $p<0.01$.

Considering that colour parameters were more closely correlated among the $\mathrm{h}^{*}$ values and the visual attributes RCI, SDI, and RCA, a linear regression was determined among them (Figure 6). As seen in Figure 5, consumer evaluation for RCA $\left(R^{2}=0.8662\right)$ (Figure 6a) and RCI $\left(R^{2}=0.8977\right)$ (Figure $\left.6 \mathrm{~b}\right)$ linearly increased with the $\mathrm{h}^{*}$ decrease. On the contrary, concerning SDI values (Figure 6c), measurements were positively correlated, and consumer scores attributed to SDI $\left(R^{2}=0.9182\right)$ increased linearly with $\mathrm{h}^{*}$. Our results demonstrated that $h^{*}$ can reflect consumers colour evaluation for RCI, SDI, and RCA. 


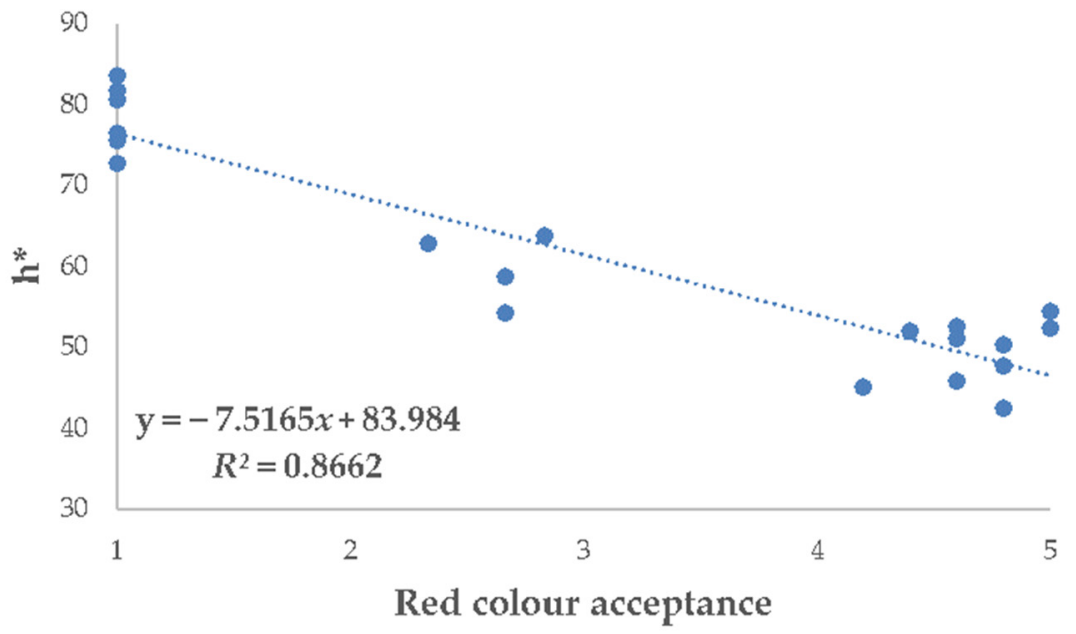

(a)

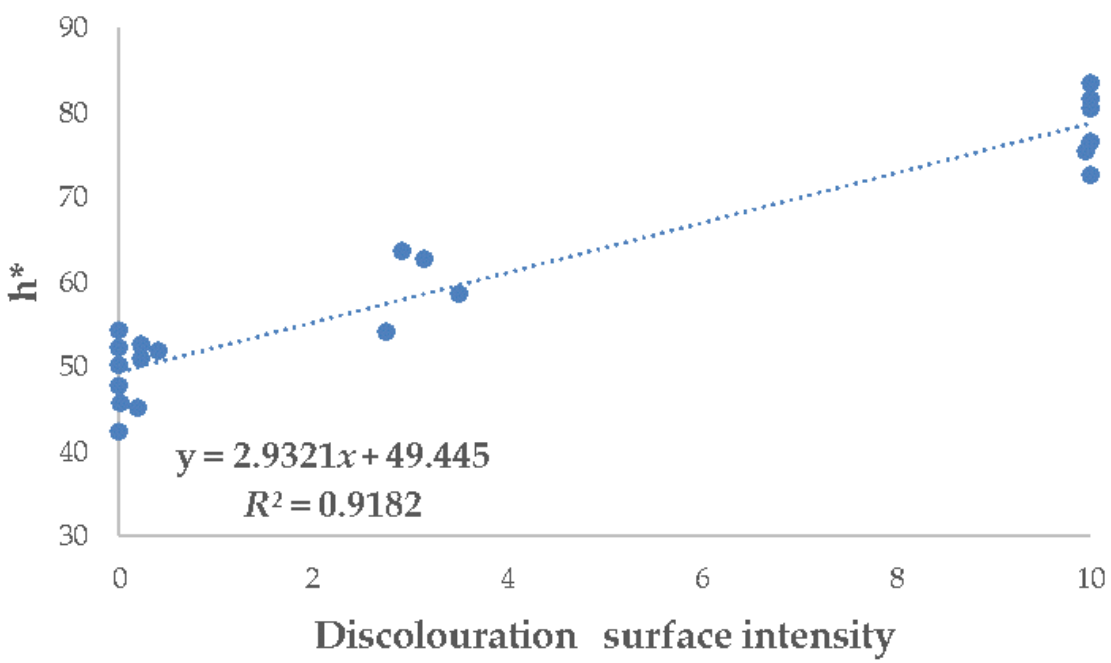

(b)

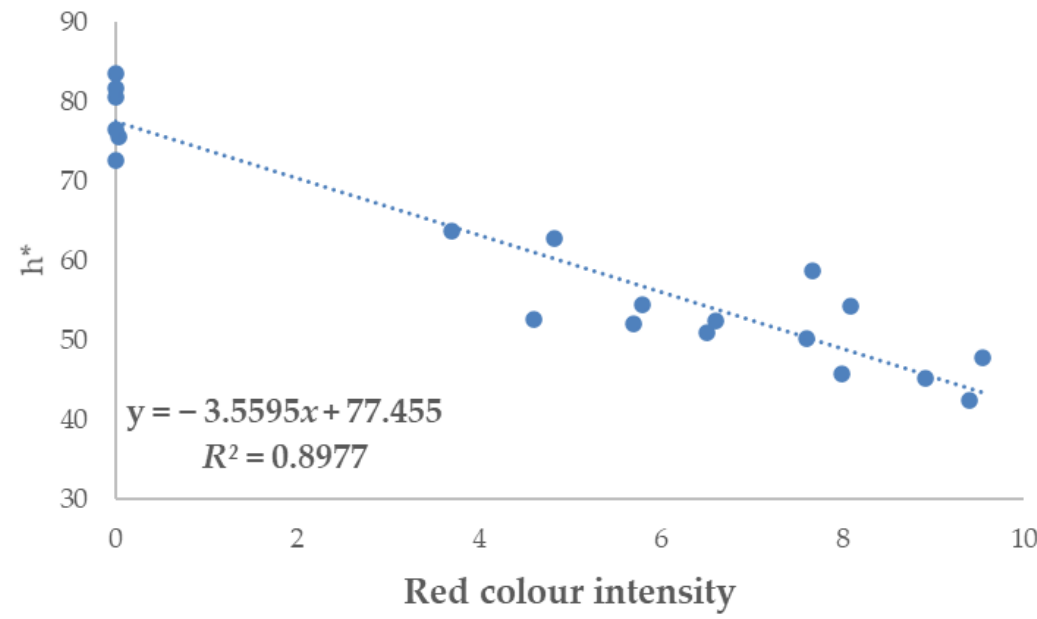

(c)

Figure 6. (a) Relationship between $\mathrm{h}^{*}$ and red colour acceptance; (b) Relationship between $\mathrm{h}^{*}$ and red colour intensity; (c) Relationship between $\mathrm{h}^{*}$ and discolouration surface intensity. 


\section{Discussion}

4.1. Total Phenolic Content (TPC), Total Anthocyanin (TAC), and Phenolic Profile of Colombian Berry (V. meridionale Sw.) Extract (CBE)

The previous studies that identified and quantified the phenolic compounds in fresh fruit, pomace, and other fruits derivatives [18-20] concluded that, in the V. meridionale Sw., the content of these compounds was quite high compared to other Vaccinium species. Thus, it can be considered as a promissory fruit to be employed in the food industry. However, the possible use of Colombian berry as an ingredient in food preparations has still been scarcely studied. In this sense, the identification and quantification of the polyphenolic profile of their extracts from fruits or by-products as a source of nutraceuticals or natural additives are of paramount importance to determine and optimize their further utilization.

The $83,976.25 \mathrm{mg} \mathrm{GAE} / \mathrm{kg}$ of TPC achieved in the CBE and elaborated in the present study is lower than that reported by Quintero-Quiroz et al. [20] in a freeze-dried extract made from this fruit $(139,290 \mathrm{mg} \mathrm{GAE} / \mathrm{kg})$. The extracts elaborated from this fruit by López-Padilla et al. [21] by ultrasound-assisted extraction and pressurized liquid extraction had TPC contents between $71.70 \pm 6.7 \mathrm{mg}$ GAE $/ \mathrm{kg}$ and $9.26 \pm 2.52 \mathrm{mg} \mathrm{GAE} / \mathrm{kg}$. Different and fundamental aspects have to be considered to explain these differences. On the one hand, as it is widely reported for other fruits, it is evident that the methodology used for the preparation has a great influence on the release of polyphenolic substances from the raw material [18].

Moreover, it is evident that the initial TPC of that raw material also has a great effect, as does the fact that the content and type of polyphenols in seeds, pulp, and peel are different, hence the proportion in which these parts are in the raw material has to be considered. Indeed, plant extracts are richer sources of TPC than plant compounds (e.g., seeds, peels, flowers, or leaves) $[3,8,35]$ and their use are generally preferred since are needed in small quantities to be effective [3]. For instance, in the studies of the Garzon group [18,19], the differences in TPC content (pomace $>$ whole fruit) obtained were attributed to the presence/absence of seeds and peels, which contain a larger amount of phenolic compounds, especially anthocyanins and procyanidins [18]. Additionally, it has also been reported that plant phenolics show qualitative and quantitative variation at genetic levels, physiological, and developmental stages of the plant. Phenolics also vary in response to environmental factors, such as light intensity and nutrient availability [12]. All these factors may contribute to the differences in phenolic profiles reported in the literature.

For comparative purposes with different tropical fruits, our TPC values were higher than those published for red pitaya (Hylocereus monacanthus Lm. Britton \& Rose) (2681.3 mg of GAE/kg extract) [5], Cupuaçu (Theobroma grandiflorum (Willd. ex Spreng.) K. Schum.) (4970 mg GAE/kg of fresh weight), Algarrobo (Hymenaea courbaril L.) (20130 mg GAE/kg of fresh weight), and Cashew (Anacardium occidentale L.) (48,510 mg GAE $/ \mathrm{kg}$ of fresh weight) [36]. On the other hand, CBE showed lower TPC than those reported for plant extracts from grape seed (Vitis vinifera L. and Vitis labrusca L.) $(373,000 \mathrm{mg}$ GAE/ $\mathrm{kg}$ ), tea (Camellia sinensis (L.) Kuntze) (390,900 (mg GAE/kg) [37], and guarana seeds (Paullinia cupana K.) $(258,000 \mathrm{mg} / \mathrm{kg})$ [38].

The content of total anthocyanin (Table 1) found in the CBE, raw material, and fresh fruit of the Colombian berry (V. meridionale Sw.) is within the range cited in the previous works. Garzón et al. [18], Maldonado-Celis et al. [39], and Quintero-Quiroz et al. [20] reported means values of 3.29, 1.51, and 4.66 (mg cyanidin equivalents/g) for the freeze-dried Colombian berry values, respectively. Concerning fresh fruit, values of mg cyanidin-3glycoside/100 $\mathrm{g}$ in the range 92-235 mg for the northern highbush blueberry (Vaccinium corymbosum L.), 60-187 for the rabbiteye blueberry (Vaccinium ashei R.), and 290-300 for lowbush blueberry (Vaccinium angustifolium S.) have been reported by several authors [40-43].

The polyphenolic profile of CBE analysed is quite similar to that found by Vasco et al. [44] for a variety of fresh fruit mortiño (Vaccinium floribundum K.) from Ecuador and to those found by Garzón et al. [18,19] for fresh fruits and pomace (V. meridionale Sw.) from Colombia. These authors published information concerning phenolic profiles where 
anthocyanidin compounds (mostly cyanidin and delphinidin derivatives), flavanols (predominantly quercetin), and phenolic acids were the most abundant compounds. Figure 1a shows the peaks that correspond to cyanidin and delphinidin.

The presence of anthocyanins (in general) and cyanidin derivatives (in particular) are important for the antioxidant properties of CBE. Ivanovic et al. [45] found a strong linear correlation between DPPH radical scavenging activity and the content of cyanidin in extracts of blackberry cultivar "Cacanska Bestrna" cultivated in Serbia. Flavonols such as quercetin, kaempferol, and myricetin and their derivatives (primarily glycosides) are considered the dominant flavonoids in bilberries, cranberries, and lingonberries [46]. Quercetin and kaempferol derivatives were identified and quantified in the CBE (Figure 1b). The presence of quercetin derivatives was already reported by Garzon in berries and pomace from $V$. meridionale $S w$. $[18,19]$. Although kaempferol derivatives were not reported in these studies, these flavonoids compounds have been identified in Vaccinium myrtillus L. fresh fruits and extracts [47] and Vaccinium Vitis-idaea L. fresh fruits [48]. The presence of these compounds is a key factor in the nutraceutical properties of CBE. Quercetin is considered as an exceptional free radical scavenger and consequently, it is suggested to be involved in human health benefits such as cardioprotective effects and chemo-preventive effects against certain types of tumours [49]. Quercetin inhibits human platelet aggregation in vitro by inhibiting protein-tyrosine kinase [50]. Kaempferol is known for its cytotoxic, antioxidant, and apoptotic effects [51].

In our attempt to identify the individual profile of phenolic acids of $\mathrm{CBE}$, we were only able to identify and quantify the p-coumaric and syringic acid. Other identified non-flavonoid compounds (Figure 1) were below the quantification limit. The values found represented a little percentage $(<1 \%)$ of the total polyphenolic amount of CBE. In this regard, we have to take into consideration the small amounts found in the raw material, and in the fresh fruits lower than $99.2 \pm 6.7 \mathrm{mg} / 100 \mathrm{~g}$ of fresh weight reported by Garzon et al. [18]. Unlike our results, some references [18,19] showed the chlorogenic acid and caffeic acid derivatives as those more common non-flavonoid compounds in pomace and berries from $V$. meridionale. For the interpretation of these results, the amount variation of caffeic, ferulic, p-coumaric, chlorogenic acids, and the total phenolic acids in the different Vaccinium cultivars $[18,44,52,53]$, should be considered. It is also well known that the extraction method can influence determination of phenolic acids, and their concentration can vary due to different factors as environmental conditions and ripening berries. Therefore, due to the antioxidant compounds assessed in the present study for the $\mathrm{CBE}$, results suggested that the incorporation of this extract in the meat products (e.g., pork patties) could increase their shelf life and improve their nutritional properties.

\subsection{In Vitro Antioxidant Activity of Colombian Berry (V. meridionale Sw.) Extract (CBE)}

$\mathrm{DPPH}, \mathrm{IC}_{50}, \mathrm{ABTS}^{\bullet+}, \mathrm{ORAC}$, and FRAP assays were used to evaluate the in vitro antioxidant activity of CBE. DPPH results and the scavenging effects on DPPH measured as $\mathrm{IC}_{50}$ showed values of $143.68 \pm 3.87 \mu \mathrm{g} \mathrm{TE} / \mathrm{g}$ and $1.55 \pm 0.01 \mathrm{mg} / \mathrm{mL}$, respectively. Our results were lower than those obtained by Fernandes et al. [54] who assessed the antioxidant capacity by DPPH tests of 13 plant extracts, obtaining values in the range 5000 to $90,600 \mu \mathrm{g}$ TE/g of dry weight. These differences can be explained, in part, by the fact that our data are expressed on a wet basis. Concerning $\mathrm{IC}_{50}$, our findings showed lower values (higher antioxidant activity) than those reported for brown seaweed extracts (Fucus vesiculosus L.) (3.47 mg/mL) [1] and Duzhong extract (Eucommia ulmoides Oliv.) ( 2.81 and $8.43 \mathrm{mg} / \mathrm{mL}$, roasted cortex and seed, respectively) [55]. On the contrary, our results were higher (lower antioxidant activity) than those found for plant origin extracts such as chestnut (Castanea sativa Mill.) $(0.34 \mathrm{mg} / \mathrm{mL})$ [56], grape seed (Vitis vinifera L. and Vitis labrusca L.) $(0.16 \mathrm{mg} / \mathrm{mL})$, and tea (Camellia sinensis (L.) Kuntze) $(0.12 \mathrm{mg} / \mathrm{mL})$ [37]. Usually, low values of DPPH scavenging tend to provide higher values for its $\mathrm{IC}_{50}$, which indicates lower radical-scavenging activity [1]. Despite that, in the present study, lower 
values of DPPH scavenging were found when compared to several plant extracts [54], which does not mean necessarily lower antioxidant activity.

Many factors can influence the composition of a plant extract and, consequently, their antioxidant activity assays (e.g., extraction procedures) [57]. Contreras-Calderón et al. [36] reported that FRAP, $\mathrm{ABTS}^{\bullet+}$, DPPH, and ORAC are the most widely used methods to assess the antioxidant activity of the extracts. Indeed, they recommended at least two of these tests combined to provide reliable information. For this reason, in the present study, different methodologies have been employed to evaluate the in vitro antioxidant capacity of CBE.

The $\mathrm{ABTS}^{\bullet+}$ method measures the ability of the antioxidant molecule to quench $\mathrm{ABTS}^{\bullet+}$ radicals via an electron transfer reaction, assessing a radical discolouration [18]. A value of $253.27 \mathrm{~g}$ ascorbic acid $/ \mathrm{kg}$ indicates that CBE can quench $\mathrm{ABTS}^{\bullet+}$ as an electron donor. This antioxidant capacity could be attributed to a higher level of extracted nonpolar phenolic compounds and oxygenated monoterpenes in CBE that could act as direct free-radical scavengers $[2,18]$. In several studies, authors have reported ABTS ${ }^{\bullet+}$ values for CBE of $1.034 \mathrm{~mol} \mathrm{TE} / \mathrm{kg}$ [21], CB fresh fruit (327.9 $\mu \mathrm{mol} \mathrm{TE} / \mathrm{g}), \mathrm{CB}$ fresh weight $(45.5 \mathrm{~mol}$ $\mathrm{TE} / \mathrm{g})$ [18], and CB dry weight $(546.7 \mu \mathrm{mol} \mathrm{TE} / \mathrm{g})$ [19]. Moreover, values for ABTS ${ }^{\bullet+}$ of guarana seed (Paullinia cupana K.) $(2072 \mu \mathrm{mol} \mathrm{TE} / \mathrm{g})$ [38], grape seed (Vitis vinifera L. and Vitis labrusca L.) (2.93 g TE/g), and tea (Camellia sinensis (L.) Kuntze) (4.06 (g TE/g) [37] have been published.

Compared to other methods, the ORAC test has received extensive coverage and utilization in the field of antioxidants. The change in fluorescence intensity is an index of the degree of free radical damage. The inhibition of free radical damage by an antioxidant is a measure of its antioxidant capacity against the free radical [58]. Values of ORAC for the CBE of the present study (472.25 mg TE/g) were higher than those previously published for CB pomace extract (416.8 TE/g of dry weight) [19] and freeze-dried CB (159.48 mg $\mathrm{TE} / \mathrm{g})[20]$.

The FRAP assay measures the potential of an antioxidant to reduce the yellow ferric2,4,6-tri-pyridyl-s-triazine (TPTZ) complex to a blue ferrous-TPTZ complex by electrondonating molecules under acidic conditions. Concerning FRAP results, the value of $1.98 \mathrm{~mol} \mathrm{Fe}{ }^{+2} / \mathrm{kg}$ in the present study was 16 -fold higher than $0.116 \mathrm{~mol} \mathrm{Fe}^{+2} / \mathrm{kg}$ of fresh weight reported by Garzón et al. [18].

After analysing our findings in terms of in vitro antioxidant activity of CBE and comparing them with other antioxidants extracts from plant origin, it could be hypothesised that $\mathrm{CBE}$ could be used to prevent the oxidation of pork patties. This possibility will be evaluated in the next section. In a way, our results are not surprising in agreement with Lorenzo et al. [16], who recently published a review indicating the use of berry extracts as natural antioxidants in meat products. In the same line, López-Padilla et al. [21] also reported that $\mathrm{CB}$ is being valorised as raw material for the recovery of rich antioxidants with the application as natural additives in meat products. The $\mathrm{DPPH}, \mathrm{IC}_{50}, \mathrm{ABTS}^{\bullet+}, \mathrm{ORAC}$, and FRAP values obtained for the CBE can be attributed to the presence of phenolics compounds with high antioxidant and radical scavenging activity [18,19], especially anthocyanins (e.g., monoglucosides of cyanidin and delphinidin), hydroxycinnamic acids (e.g., coumaric acid), and flavanols (e.g., quercetin derivatives).

Finally, it is important to remark that different results were obtained by several authors $[18,19,21,59,60]$ for the phenolic profile and antioxidant activity of CB. This is related to the fact that phenolics and their characteristics depend significantly on the material assessed (e.g., raw fruit, pomace or extract) and/or the extraction technique utilized to prepare the samples (e.g., extraction equipment, solvents, and extraction temperatures). In addition, it is well-known that polyphenols have different abilities to scavenge free radicals [61]. For example, for $\mathrm{CB}$, it has previously been published that the antioxidant activity $\left(\mathrm{ABTS}^{\bullet+}\right)$ of the raw fruit $(0.007 \mathrm{~mol} \mathrm{TE} / \mathrm{kg})$ is extremely low when compared with its extract obtained with ethanol at $25^{\circ} \mathrm{C}(0.140 \mathrm{~mol} \mathrm{TE} / \mathrm{kg})$ or ethanol/water 50:50 at $200{ }^{\circ} \mathrm{C}(1.034 \mathrm{~mol} \mathrm{TE} / \mathrm{kg})$ [21]. In line with this, further studies will be necessary with other 
procedures to ensure a more accurate comparison and to confirm CBE phenolic profile as well its antioxidant activity.

\subsection{Evaluation of $\mathrm{pH}$ and Colour of Pork Patties during Storage}

The lower values of the $\mathrm{pH}$ of the pork patties $(p \leq 0.001)$ measured in CON, ASC, and CBE250 treatments at day 1 (CBE500 and CBE750 > CON, ASC, and CBE250) suggested that the $\mathrm{pH}$ of the extracts could have an important effect on the initial $\mathrm{pH}$ of the patties. Similar findings were reported in previous studies with pork patties formulated with grape (Vitis vinifera L.), green tea (Camellia sinensis (L.) Kuntze) [37], and watermelon (Citrullus lanatus (Thunb.) Matsum. y Nakai) rind extracts [3]. However, Peiretti et al. [62] noticed a contrary trend in pork patties elaborated with blueberry pomace, indicating the higher $\mathrm{pH}$ values in control patties with ascorbic acid together those patties formulated with a $2 \%$ of blueberry pomace, in disagreement with our results. In line with this, other studies with pork patties, enriched with plants extracts such as guarana seeds (Paullinia cupana K.) [38], thyme (Thymus serpyllum L.) [2], and pitanga leaf (Eugenia uniflora L.) $[63,64]$, have described a significantly $(p \leq 0.01)$ initial decrease in the $\mathrm{pH}$. The highest $\mathrm{pH}$ values showed in the patties with a higher extract content (CBE500 and CBE750) could be explained by the characteristics of the berry used to obtain the extract, as well as the nature of its polyphenols/active compounds among others.

As expected, the addition of CBE affected all colour parameters which seem to be directly linked with the dark red colour of the extract (Figure 4). The darkening of the pork patties as a consequence of the addition of CBE has also been noticed in other studies with blueberry [62] added to pork patties or with red-blue fruits [65] in the elaboration of chicken meat. With other types of natural extract, such as thyme (Thymus serpyllum L.) [2], green tea (Camellia sinensis (L.) Kuntze), grape (Vitis vinifera L. and Vitis labrusca L.), chestnut (Castanea sativa Mill.), and seaweed (Ulva lactuca L. and Ulva rigida C. Agardh) [37], no modification of the meat product lightness has been reported.

Concerning redness index $\left(\mathrm{a}^{*}\right)$, the lower values observed in the patties with the lowest concentration of CBE (CBE250) or without berry extract (CON and ASC) are previously reported by authors that attributed these reductions to lipid oxidation $[2,66]$. This redness loss in the patties during the storage is probably associated with the myoglobin oxidation, which is red in its reduced form and brown in the corresponding oxidized ferric form [67]. This discolouration can be alleviated by reducing the formation of metmyoglobin using plant extracts, particularly those rich in monoterpene polyphenols [66,68].

The $C^{*}$ (saturation index) is related to pigment concentration and refers to the colour intensity or its relative strength, and therefore is different to $L^{*}$ which instead measures colour lightness when compared against a white standard. This suggests $C^{*}$ as a better means to account for the qualitative-determined importance of red colour brightness [69]. During storage time and until the 9 th day, the $C^{*}$ parameter decreased $(p \leq 0.001)$, but in a different way among treatments. This means that patties throughout storage displayed a less vivid colour and were close to grey.

As the $\mathrm{h}^{*}$ parameter is calculated based on $\mathrm{a}^{*}$ and $\mathrm{b}^{*}$, a higher $\mathrm{h}^{*}$ means the development of colour from red to yellow. Indeed, $\mathrm{h}^{*}$ is considered as a measure of colour change noticeable by the human eye and represents colour stability [70]. An increasing trend in the $h^{*}$ values during storage time and until the ninth day was assessed in the present study, the $h^{*}$ parameter raised $(p \leq 0.001)$ indicating gradual oxidation of myoglobin and accumulation of metmyoglobin with time [71]. Therefore, a higher $\mathrm{h}^{*}$ detected in CON (CON, CBE250 > CBE500 > CBE750, respectively) would indicate colour development of these patties to a smaller redness index, suggesting higher oxidation during the storage.

The colour difference $(\Delta \mathrm{E})$ is described by the National Bureau of Standards Unit, stating that there are small differences among colours that are detectable by humans: 0-0.5 (trace), 0.5-1.5 (slight), 1.5-3.0 (noticeable), 3.0-6.0 (appreciable), 6.0-12.0 (much), $>12.0$ (very much) [68]. Consequently, according to these standards, in the present study, the colour differences were "much detectable" throughout the storage until day $6\left(\Delta \mathrm{E}_{\mathrm{s}}>6\right)$, and 
in a similar way among the three treatments when compared to CON. On the opposite, on day 9 of storage, all samples showed significant $(p \leq 0.01)$ differences in $\Delta \mathrm{E}_{\mathrm{s}}$ among them, which means that colour difference $\left(\Delta \mathrm{E}_{\mathrm{s}}>3\right)$ could be "appreciable" for each treatment [68]. Our results agree with a previous study with beef patties that evaluated the potential of $\mathrm{CB}$ to protect myoglobin, as well as its global contribution to product colour. The findings of the study led to an evident total colour difference between treated and control samples $\left(\Delta \mathrm{E}_{\mathrm{s}}\right)$ in which the treated samples could be discriminate from the control [21].

Changes in the colour of CON patties were expected since previously it has been reported that, when the patties are kept refrigerated, samples without antioxidants suffer a more intense deterioration of $\mathrm{L}^{*}, \mathrm{~b}^{*}$, and especially $\mathrm{a}^{*}$ values. Indeed, this decreasing tendency is expected and very characteristic in raw meat and meat preparations [21]. However, despite our data suggesting a potentially lower rate of colour deterioration of patties elaborated with $\mathrm{CBE}$, it should be noted that it is not advisable to use a $\Delta \mathrm{E}$ value as a single way to measure colour deterioration since $\Delta E$ involves changes of $L^{*}, a^{*}$, and $b^{*}$ which do not always change in parallel [68].

\subsection{Evaluation of Lipid Oxidation and $\Delta E_{t}$ of Pork Patties during Storage}

Increased lipid oxidation observed in the samples is likely due to endogenous enzymatic activity (e.g., lipoxygenase). Furthermore, the protein degradation process of myoglobin stimulates the release of high concentrations of free iron with high prooxidant potential [2]. Therefore, as predicted, TBARS values were higher in the CON batch, but they significantly $(p \leq 0.001)$ increased in all treatments during the storage, characterizing the progression of lipid oxidation. However, concerning patties with antioxidants (ASC and CBE), only CBE750 treatment maintained TBARS values below $0.5 \mathrm{mg}$ MDA $/ \mathrm{kg}$ over a storage period ( 9 days), which is marked as an acceptable sensory limit for revealing rancid flavour [72].

Our results for the initial TBARS values showed no significant $(p>0.05)$ differences among batches, as one might expect. In disagreement, López-Padilla et al. [21] reported significant differences in TBARs values in beef patties elaborated with CBE at day 0 . The authors attributed these differences to CBE pigments (authors used 20,000 ppm of $\mathrm{CBE}$ ) as they are capable to absorb light in the same wavelength range as MDA.

In the present study, although significant differences were observed in colour parameters (Table 3) among treated samples (day 1), this effect was not observed on TBARS values. It can thus be suggested that CBE has an immediate effect on the colour of the patties, especially in $\mathrm{L}^{*}$ and $\mathrm{a}^{*}$, previously to preservation exerted by active compounds (polyphenols). This finding has an interesting implication on the use of CBE with a dual purpose (as a natural colourant and as an antioxidant). In the present study, the CBE250 and CBE500 batches had similar values for TBARS when compared to the ASC group. These results showed that CBE might be a potent antioxidant in the control of lipid oxidation during refrigerated storage, as no prooxidant effect attributable to $\mathrm{CBE}$ was found in the studied range (250 to $750 \mathrm{ppm}$ ). Nonetheless, existent literature on the use of CBE as an antioxidant ingredient in foods is scarce. Further studies evaluating the addition of CBE to other complex meat matrices, such as meat emulsions or meat cooked products, are necessary to corroborate this information.

Even though lower $\mathrm{L}^{*}$ and $\mathrm{h}^{*}$ and higher $\mathrm{a}^{*}$ and $\mathrm{b}^{*}$ were obtained for CBE500 and CBE750 treatments in comparison to CON batch, no significant $(p \geq 0.05)$ differences were observed for $\triangle \mathrm{E}_{\mathrm{t}}$ among samples at the end of the experiment (day 1 vs. 9). Thus, except for day 1 vs. 6, no positive effect of CBE on the colour of the patties concerning CON was observed. In addition, all patties (CON and CBE treatment) showed $\Delta \mathrm{E}_{\mathrm{t}}$ values between 2.33-4.22 (day 1 vs. 3) and 11.52-14.28 (day 1 vs. 9), which is over the value of 2, and considered a limit to appreciate visual colour changes [37]. Therefore, results would indicate that consumers will perceive colour changes suffered by patties during storage (days 3, 6, and 9) for each treatment. Finally, the findings of the current study for the TBARS correlation with colour parameters (positive correlation with $\mathrm{L}^{*}$ and $\mathrm{h}^{*}$ and 
negative correlation with $\mathrm{a}^{*}$ ) were partially in agreement with Nassu et al. [71]. They also found an increasing/decreasing trend for lipid oxidation and colours parameters; however, with a negative correlation among TBARS with $\mathrm{a} *$ and $\mathrm{C}^{*}$ and a positive correlation between TBARS and $h^{*}$. Still, as previously discussed for colour (Section 4.3), $\Delta \mathrm{E}_{\mathrm{s}}$, and lipid oxidation (Section 4.4), it is not advisable to use this parameter as a single way to measure colour deterioration [68].

\subsection{Sensory Analysis \\ 4.5.1. Sensory Acceptance}

The possible benefits of the inclusion of plant extracts on meat products cannot diminish their sensory characteristics, specifically colour. Indeed, consumer acceptability is one of the critical factors for the development of new foodstuffs [56]. In line with this, our outcomes for sensory acceptance (appearance, raw odour, cooked odour, texture, taste, and overall impression) showed scores $>4.2$ for all CBE treatments on the hedonic scale (over "acceptable"). This result could be attributed to the CBE phenolic profile. In this regard, Pateiro et al. [35] corroborated those compounds, such as hydroxycinnamic acid, anthocyanins, tannins, and flavonoids, could be responsible for the quality improvement of pork patties, resulting in a product with higher sensory acceptability.

The high liking score results obtained from the hedonic tests are extremely encouraging since this is not always the case in the reformulation and development of functional meat products [61]. As the preference score averages can be considered an appropriate means to determine consumer acceptance [56], our results indicate that CBE could be added as an additive into pork patties without impairing sensory attributes.

4.5.2. Visual Attributes Evaluation during Shelf-Life: Red Colour Intensity (RCI) and Surface Discolouration Intensity (SDI)

The incorporation of CBE into pork patties modified the RCI (CBE250, CBE500, CBE750 $>\mathrm{CON}, \mathrm{ASC}$ ) on day 1 and during the storage until day 6. Conversely, the CBE effect on SDI was comparable to ASC since all treatments, except for CON, showed similar scores for this attribute in the same period. Colombian berries are fruits with a purple-dark colour at maturity [20]. Therefore, the CBE affected the RCI (Figure 4) due to its natural pigments rich in anthocyanins (e.g., monoglycosides of cyanidin and delphinidin) and flavanols (e.g., quercetin derivatives) $[18,19]$. Although, the effect on the colour indicated that only the highest doses of CBE (CBE500 and CBE750) were effective to remain colour stable (RCI) until day 6.

In addition, visual attributes showed can be associated with the lower $\mathrm{h}^{*}$ values determined in CBE pork patties (especially CBE500 and CBE750; Table 3). The effect on $\mathrm{h}^{*}$ value of meat products is related to the antioxidative compounds that can preserve a red/purplish colour and prevent SDI on patties, reducing oxidation of $\mathrm{Mb}$ (metmyoglobin formation), which is red in its reduced-ferric form and brown in its oxidized-ferric form $[66,68,73,74]$.

This positive effect on colour supports the feasibility of using CBE with a dual purpose (as an antioxidant and natural pigment), avoiding the use of synthetic antioxidants and colourants with this purpose. This result for CBE is encouraging since the consumer's decision to purchase meat products is greatly influenced by colour [75]. Indeed, consumer preference for meat colour is not sufficient to affect taste ratings but is sufficient to affect their likelihood of purchasing [76]. Consequently, comparing the effect of CBE treatments to ASC on pork patties, it seems that CBE was more effective in maintaining RCI and had a similar effect on SDI. Overall, this study has shown that CBE has the potential as a natural preservative to reduce colour degradation.

\subsubsection{Correlations between Colour Measurements and Visual Attributes of Pork Patties}

As mentioned previously, colour is the most important quality attribute for consumers since it is an indicator of freshness. Numerous studies evaluating the shelf-life of meat 
products use instrumental measurements to determine their colour. However, although these variables are very useful to typify this parameter, their use raises doubts about how humans perceive or evaluate meat products. In addition, it is difficult to define when these products will be rejected by consumers [34].

Visual evaluation affords the advantages of being able to make a global appraisal of the colour status of the entire measurement surface rather than having to take readings for only a few individual points. Conversely, the colour comparison standards may be rendered unsuitable or may become hard to apply because of factors, such as differences in lighting (metamerism) [77], availability of trained/untrained panellists, or the lack of ability of the trained panel to detect variations among storage time and treatments [71]. On the other hand, instrumental colour readings, by comparison, offer the advantage of not being subject to variation with changes in lighting or consumers. Putting aside economic and/or availability possibilities, overall, both instrumental and visual colour measurements have advantages and disadvantages, but they are complementary to the interpretation of results, and should be taken whenever possible.

The regression coefficient $\left(R^{2}\right.$ ranging between $\left.0-1\right)$ shows the accuracy of a model, whereby if this value is higher than 0.70 , it indicates that the model is well adjusted [78]. All the $R^{2}$ values obtained in the present study were above this target value $(>0.86)$. Our data showed that a strong relationship among $\mathrm{h}^{*}, \mathrm{RCI}, \mathrm{SDI}$, and shelf-life of pork patties exists. This correlation with the instrumental colour measurements corroborates the usefulness of the colour comparison reference standards for its use in visual colour evaluations. At the same time, visual appraisals of colour that were closely correlated with the instrumental were useful to assess the panellist's accuracy. Finally, our results agree with Wang et al. [79] that have demonstrated that $h^{*}$ measurements could reflect consumers colour evaluation.

\section{Conclusions}

The evidence from this study suggests that CBE has the potential as a novel food additive to prevent lipid oxidation during pork patties' shelf-life. The CBE displayed greater antioxidant activity in protecting the patties against lipid oxidation during storage, as confirmed by the decrease in TBARS (especially for a dose of $750 \mathrm{mg} / \mathrm{kg}$ ), which provided a higher extended shelf life until day 6 in comparison to control. In addition, CBE could be advantageously incorporated in pork patties without causing detrimental changes in their sensory properties since this did not alter their overall liking of them. Furthermore, as the extracts reduced the loss of redness by delaying discolouration, our findings support the idea that they could be used as a natural antioxidant in meat products as substitutes for synthetic antioxidants. Further investigations should evaluate the ability of CBE as a potential substitute for curing agents in fermented, cured, and cooked meat products, as well to explore its utilization in nutraceutical, pharmaceutical, and food applications associated with its content in interesting polyphenolic compounds.

Author Contributions: Conceptualization, M.V.-R., J.M.L., S.Z. and D.F.; formal analysis, M.V.-R., S.Z., M.E.V., D.M.; writing—original draft preparation, M.V.-R. and S.Z.; writing—review and editing, M.V.-R., S.Z., M.E.V., J.M.L., M.C.G.B., J.M.F.-A., J.F.R. and D.F. All authors have read and agreed to the published version of the manuscript.

Funding: This research was funded by CYTED (Programa Iberoamericano de Ciencia y Tecnología para el desarrollo (ref. 119RT0568). Authors (J.M.L., D.F., M.C.G., J.F.F., J.F.R.) are members of the HealthyMeat network, funded by CYTED (ref. 119RT0568). Thanks to GAIN (Axencia Galega de Innovación) for supporting this research (grant number IN607A2019/01). Sol Zamuz acknowledges the financial support PTA program (PTA2017-141).

Institutional Review Board Statement: The study was conducted in accordance with the Declaration of Helsinki, and the protocol was approved by the local committee of Centro Tecnológico de la Carne (SEN/2021).

Informed Consent Statement: Informed consent was obtained from all subjects involved in the study. 
Data Availability Statement: Data is contained within the article.

Conflicts of Interest: The authors declare no conflict of interest.

\section{References}

1. Agregán, R.; Barba, F.J.; Gavahian, M.; Franco, D.; Khaneghah, A.M.; Carballo, J.; Ferreira, I.C.F.R.; da Silva Barretto, A.C.; Lorenzo, J.M. Fucus vesiculosus extracts as natural antioxidants for improvement of physicochemical properties and shelf life of pork patties formulated with oleogels. J. Sci. Food Agric. 2019, 99, 4561-4570. [CrossRef]

2. S Šojić, B.; Tomović, V.; Kocić-Tanackov, S.; Kovačević, D.B.; Putnik, P.; Mrkonjić, Ž.; Đurović, S.; Jokanović, M.; Ivić, M.; Škaljac, S.; et al. Supercritical extracts of wild thyme (Thymus serpyllum L.) by-product as natural antioxidants in ground pork patties. LWT 2020, 130, 109661. [CrossRef]

3. Kumar, P.; Mehta, N.; Malav, O.P.; Kumar Chatli, M.; Rathour, M.; Kumar Verma, A. Antioxidant and antimicrobial efficacy of watermelon rind extract (WMRE) in aerobically packaged pork patties stored under refrigeration temperature $\left(4 \pm 1^{\circ} \mathrm{C}\right)$. J. Food Process. Preserv. 2018, 42,jfpp.13757. [CrossRef]

4. Agregán, R.; Lorenzo, J.M.; Munekata, P.E.S.; Dominguez, R.; Carballo, J.; Franco, D. Assessment of the antioxidant activity of Bifurcaria bifurcata aqueous extract on canola oil. Effect of extract concentration on the oxidation stability and volatile compound generation during oil storage. Food Res. Int. 2017, 99, 1095-1102. [CrossRef]

5. Bellucci, E.R.B.; Munekata, P.E.S.; Pateiro, M.; Lorenzo, J.M.; da Silva Barretto, A.C. Red pitaya extract as natural antioxidant in pork patties with total replacement of animal fat. Meat Sci. 2021, 171, 108284. [CrossRef]

6. Tomasevic, I.; Tomovic, V.; Milovanovic, B.; Lorenzo, J.; Đorđević, V.; Karabasil, N.; Djekic, I. Comparison of a computer vision system vs. traditional colorimeter for color evaluation of meat products with various physical properties. Meat Sci. 2019, 148, 5-12. [CrossRef]

7. Lorenzo, J.M.; González-Rodríguez, R.M.; Sánchez, M.; Amado, I.R.; Franco, D. Effects of natural (grape seed and chestnut extract) and synthetic antioxidants (buthylatedhydroxytoluene, BHT) on the physical, chemical, microbiological and sensory characteristics of dry cured sausage "chorizo". Food Res. Int. 2013, 54, 611-620. [CrossRef]

8. Ramírez-Rojo, M.I.; Vargas-Sánchez, R.D.; del Mar Torres-Martínez, B.; Torrescano-Urrutia, G.R.; Lorenzo, J.M.; Sánchez-Escalante, A. Inclusion of ethanol extract of mesquite leaves to enhance the oxidative stability of pork patties. Foods 2019, 8, 631. [CrossRef] [PubMed]

9. Cunha, L.C.M.; Monteiro, M.L.G.; da Costa-Lima, B.R.C.; Guedes-Oliveira, J.M.; Rodrigues, B.L.; Fortunato, A.R.; Baltar, J.D.; Tonon, R.V.; Koutchma, T.; Conte-Junior, C.A. Effect of microencapsulated extract of pitaya (Hylocereus costaricensis) peel on oxidative quality parameters of refrigerated ground pork patties subjected to UV-C radiation. J. Food Process. Preserv. 2021, 45, 15272. [CrossRef]

10. Varvara, M.; Bozzo, G.; Celano, G.; Disanto, C.; Pagliarone, C.N.; Celano, G.V. The use of ascorbic acid as a food additive: Technical-legal issues. Ital. J. food Saf. 2016, 5, 7-10. [CrossRef] [PubMed]

11. Munekata, P.E.S.; Rocchetti, G.; Pateiro, M.; Lucini, L.; Domínguez, R.; Lorenzo, J.M. Addition of plant extracts to meat and meat products to extend shelf-life and health-promoting attributes: An overview. Curr. Opin. Food Sci. 2020, 31, 81-87. [CrossRef]

12. Vargas-Ramella, M.; Pateiro, M.; Gavahian, M.; Franco, D.; Zhang, W.; Mousavi Khaneghah, A.; Guerrero-Sánchez, Y.; Lorenzo, J.M. Impact of pulsed light processing technology on phenolic compounds of fruits and vegetables. Trends Food Sci. Technol. 2021, 115, 1-11. [CrossRef]

13. Alirezalu, K.; Pateiro, M.; Yaghoubi, M.; Alirezalu, A.; Peighambardoust, S.H.; Lorenzo, J.M. Phytochemical constituents, advanced extraction technologies and techno-functional properties of selected Mediterranean plants for use in meat products. A comprehensive review. Trends Food Sci. Technol. 2020, 100, 292-306. [CrossRef]

14. Pateiro, M.; Barba, F.J.; Domínguez, R.; Sant'Ana, A.S.; Mousavi Khaneghah, A.; Gavahian, M.; Gómez, B.; Lorenzo, J.M. Essential oils as natural additives to prevent oxidation reactions in meat and meat products: A review. Food Res. Int. 2018, 113, 156-166. [CrossRef] [PubMed]

15. Franco, D.; Pateiro, M.; Rodríguez Amado, I.; López Pedrouso, M.; Zapata, C.; Vázquez, J.A.; Lorenzo, J.M. Antioxidant ability of potato (Solanum tuberosum) peel extracts to inhibit soybean oil oxidation. Eur. J. Lipid Sci. Technol. 2016, 118, 1891-1902. [CrossRef]

16. Lorenzo, J.M.; Pateiro, M.; Domínguez, R.; Barba, F.J.; Putnik, P.; Kovačević, D.B.; Shpigelman, A.; Granato, D.; Franco, D. Berries extracts as natural antioxidants in meat products: A review. Food Res. Int. 2018, 106, 1095-1104. [CrossRef]

17. Shahidi, F.; Ambigaipalan, P. Phenolics and polyphenolics in foods, beverages and spices: Antioxidant activity and health effects-A review. J. Funct. Foods 2015, 18, 820-897. [CrossRef]

18. Garzón, G.A.; Narváez, C.E.; Riedl, K.M.; Schwartz, S.J. Chemical composition, anthocyanins, non-anthocyanin phenolics and antioxidant activity of wild bilberry (Vaccinium meridionale Swartz) from Colombia. Food Chem. 2010, 122, 980-986. [CrossRef]

19. Garzón, G.A.; Soto, C.Y.; López, R.M.; Riedl, K.M.; Browmiller, C.R.; Howard, L. Phenolic profile, in vitro antimicrobial activity and antioxidant capacity of Vaccinium meridionale Swartz pomace. Heliyon 2020, 6, e03845. [CrossRef] [PubMed]

20. Quintero-Quiroz, J.; Galvis-Pérez, Y.; Galeano-Vásquez, S.; Marín-Echeverri, C.; Franco-Escobar, C.; Ciro-Gómez, G.; NúñezRangel, V.; Aristizábal-Rivera, J.C.; Barona-Acevedo, J. Physico-chemical characterization and antioxidant capacity of the colombian berry (Vaccinium meridionale Swartz) with a high-polyphenol content: Potential effects in people with metabolic syndrome. Food Sci. Technol. 2019, 39, 573-582. [CrossRef] 
21. López-Padilla, A.; Martín, D.; Villanueva Bermejo, D.; Jaime, L.; Ruiz-Rodriguez, A.; Restrepo Flórez, C.E.; Rivero Barrios, D.M.; Fornari, T. Vaccinium meridionale Swartz extracts and their addition in beef burgers as antioxidant ingredient. J. Sci. Food Agric. 2018, 98, 377-383. [CrossRef] [PubMed]

22. FAO Sources of Meat. Available online: http://www.fao.org/ag/againfo/themes/es/meat/backgr_sources.html (accessed on 15 May 2021).

23. Re, R.; Pellegrini, N.; Proteggente, A.; Pannala, A.; Yang, M.; Rice-Evans, C. Antioxidant activity applying an improved ABTS radical cation decolorization assay. Free Radic. Biol. Med. 1999, 26, 1231-1237. [CrossRef]

24. Singleton, V.L.; Rossi, J.A. Colorimetry of total phenolics with phosphomolybdic-phosphotungstic acid reagents. Am. J. Enol. Vitic. 1965, 16, 144-158.

25. Lee, J.; Durst, R.W.; Wrolstad, R.E. Determination of total monomeric anthocyanin pigment content of fruit juices, beverages, natural colorants, and wines by the $\mathrm{pH}$ differential method: Collaborative study. J. AOAC Int. 2005, 88, 1269-1278. [CrossRef]

26. Portu, J.; López, R.; Baroja, E.; Santamaría, P.; Garde-Cerdán, T. Improvement of grape and wine phenolic content by foliar application to grapevine of three different elicitors: Methyl jasmonate, chitosan, and yeast extract. Food Chem. 2016, 201, 213-221. [CrossRef]

27. Castillo-Muñoz, N.; Gómez-Alonso, S.; García-Romero, E.; Hermosín-Gutiérrez, I. Flavonol profiles of Vitis vinifera red grapes and their single-cultivar wines. J. Agric. Food Chem. 2007, 55, 992-1002. [CrossRef] [PubMed]

28. ISO. UNE-EN ISO 8589:2010/A1: 2014. Sensory Analysis—General Guidance for the Design of Test Rooms; UNE: Madrid, Spain, 2014.

29. Macfie, H.J.; Bratchell, N.; Greenhoff, K.; Vallis, L.V. Designs to balance the effect of order of presentation and first-order carry-over effects in hall tests. J. Sens. Stud. 1989, 4, 129-148. [CrossRef]

30. Meilgaard, M.C.; Civille, G.V.; Carr, B.T. Sensory Evaluation Techniques, 4th ed.; Taylor and Francis Group: Boca Raton, FL, USA, 2007.

31. Pateiro, M.; Lorenzo, J.M.; Diaz, S.; Gende, J.A.; Fernandez, M.; Gonzalez, J.; Garcia, L.; Rial, F.J.; Franco, D. Meat quality of veal: Discriminatory ability of weaning status. Spanish J. Agric. Res. 2013, 11, 1044-1056. [CrossRef]

32. AMSA Meat Color Measurement Guidelines. Available online: https://meatscience.org/publications-resources/printedpublications/amsa-meat-color-measurement-guidelines (accessed on 15 May 2021).

33. Yudd, D.B.; Wyszcki, G. Color in Business, Science and Industry; Wiley: New York, NY, USA, 1975.

34. Ripoll García, G.; Panea Doblado, B.; Albertí Lasalle, P. Apreciación visual de la carne bovina y su relación con el espacio de color CIELab. ITEA 2012, 108, 222-232.

35. Pateiro, M.; Gómez-Salazar, J.A.; Jaime-Patlán, M.; Sosa-Morales, M.E.; Lorenzo, J.M. Plant extracts obtained with green solvents as natural antioxidants in fresh meat products. Antioxidants 2021, 10, 181. [CrossRef]

36. Contreras-Calderón, J.; Calderón-Jaimes, L.; Guerra-Hernández, E.; García-Villanova, B. Antioxidant capacity, phenolic content and vitamin C in pulp, peel and seed from 24 exotic fruits from Colombia. Food Res. Int. 2011, 44, 2047-2053. [CrossRef]

37. Lorenzo, J.M.; Sineiro, J.; Amado, I.R.; Franco, D. Influence of natural extracts on the shelf life of modified atmosphere-packaged pork patties. Meat Sci. 2014, 96, 526-534. [CrossRef]

38. Pateiro, M.; Vargas, F.C.; Chincha, A.A.I.A.; Sant'Ana, A.S.; Strozzi, I.; Rocchetti, G.; Barba, F.J.; Domínguez, R.; Lucini, L.; do Amaral Sobral, P.J.; et al. Guarana seed extracts as a useful strategy to extend the shelf life of pork patties: UHPLC-ESI/QTOF phenolic profile and impact on microbial inactivation, lipid and protein oxidation and antioxidant capacity. Food Res. Int. 2018, 114, 55-63. [CrossRef]

39. Maldonado-Celis, M.E.; Arango-Varela, S.S.; Rojano, B.A. Free radical scavenging capacity and cytotoxic and antiproliferative effects of Vaccinium meridionale Sw. agains colon cancer cell lines. Rev. Cuba. Plantas Med. 2014, 19, 172-184.

40. Prior, R.L.; Cao, G.; Martin, A.; Sofic, E.; McEwen, J.; O’Brien, C.; Lischner, N.; Ehlenfeldt, M.; Kalt, W.; Krewer, G.; et al. Antioxidant capacity as influenced by total phenolic and anthocyanin content, maturity, and variety of Vaccinium species. J. Agric. Food Chem. 1998, 46, 2686-2693. [CrossRef]

41. Kalt, W.; Dufour, D. Health functionality of blueberries. Horttechnology 1997, 7, 216-221. [CrossRef]

42. Capocasa, F.; Scalzo, J.; Mezzetti, B.; Battino, M. Combining quality and antioxidant attributes in the strawberry: The role of genotype. Food Chem. 2008, 111, 872-878. [CrossRef]

43. Wang, S.Y.; Ballington, J.R. Free radical scavenging capacity and antioxidant enzyme activity in deerberry (Vaccinium stamineum L.) LWT Food Sci. Technol. 2007, 40, 1352-1361. [CrossRef]

44. Vasco, C.; Riihinen, K.; Ruales, J.; Kamal-Eldin, A. Chemical composition and phenolic compound profile of mortiño (Vaccinium floribundum Kunth). J. Agric. Food Chem. 2009, 57, 8274-8281. [CrossRef]

45. Ivanovic, J.; Tadic, V.; Dimitrijevic, S.; Stamenic, M.; Petrovic, S.; Zizovic, I. Antioxidant properties of the anthocyanin-containing ultrasonic extract from blackberry cultivar "Čačanska Bestrna". Ind. Crops Prod. 2014, 53, 274-281. [CrossRef]

46. Häkkinen, S.H.; Kärenlampi, S.O.; Heinonen, I.M.; Mykkänen, H.M.; Törronen, A.R. Content of the flavonols quercetin, myricetin, and kaempferol in 25 edible berries. J. Agric. Food Chem. 1999, 47, 2274-2279. [CrossRef] [PubMed]

47. Milivojević, J.; Rakonjac, V.; Akšić, M.F.; Pristov, J.B.; Maksimović, V. Classification and fingerprinting of different berries based on biochemical profiling and antioxidant capacity. Pesqui. Agropecu. Bras. 2013, 48, 1285-1294. [CrossRef]

48. Ek, S.; Kartimo, H.; Mattila, S.; Tolonen, A. Characterization of phenolic compounds from lingonberry (Vaccinium vitis-idaea). J. Agric. Food Chem. 2006, 54, 9834-9842. [CrossRef] [PubMed] 
49. Formica, J.V.; Regelson, W. Review of the biology of quercetin and related bioflavonoids. Food Chem. Toxicol. 1995, 33, 1061-1080. [CrossRef]

50. Sakkiadi, A.V.; Stavrakakis, M.N.; Haroutounian, S.A. Direct HPLC assay of five biologically interesting phenolic antioxidants in varietal Greek red wines. LWT Food Sci. Technol. 2001, 34, 410-413. [CrossRef]

51. Ren, J.; Lu, Y.; Qian, Y.; Chen, B.; Wu, T.; Ji, G. Recent progress regarding kaempferol for the treatment of various diseases (Review). Exp. Ther. Med. 2019, 18, 2759-2776. [CrossRef]

52. Taruscio, T.G.; Barney, D.L.; Exon, J. Content and profile of flavanoid and phenolic acid compounds in conjunction with the antioxidant capacity for a variety of Northwest Vaccinium Berries. J. Agric. Food Chem. 2004, 52, 3169-3176. [CrossRef] [PubMed]

53. Määttä-Riihinen, K.R.; Kamal-Eldin, A.; Mattila, P.H.; González-Paramás, A.M.; Törrönen, R. Distribution and contents of phenolic compounds in eighteen scandinavian berry species. J. Agric. Food Chem. 2004, 52, 4477-4486. [CrossRef]

54. Fernandes, R.P.P.; Trindade, M.A.; Tonin, F.G.; Lima, C.G.; Pugine, S.M.P.; Munekata, P.E.S.; Lorenzo, J.M.; de Melo, M.P. Evaluation of antioxidant capacity of 13 plant extracts by three different methods: Cluster analyses applied for selection of the natural extracts with higher antioxidant capacity to replace synthetic antioxidant in lamb burgers. J. Food Sci. Technol. 2016, 53, 451-460. [CrossRef] [PubMed]

55. Xu, Z.; Tang, M.; Li, Y.; Liu, F.; Li, X.; Dai, R. Antioxidant properties of du-zhong (Eucommia ulmoides Oliv.) extracts and their effects on color stability and lipid oxidation of raw pork patties. J. Agric. Food Chem. 2010, 58, 7289-7296. [CrossRef]

56. Zamuz, S.; López-Pedrouso, M.; Barba, F.J.; Lorenzo, J.M.; Domínguez, H.; Franco, D. Application of hull, bur and leaf chestnut extracts on the shelf-life of beef patties stored under MAP: Evaluation of their impact on physicochemical properties, lipid oxidation, antioxidant, and antimicrobial potential. Food Res. Int. 2018, 112, 263-273. [CrossRef]

57. Shah, M.A.; Bosco, S.J.D.; Mir, S.A. Plant extracts as natural antioxidants in meat and meat products. Meat Sci. 2014, 98, 21-33. [CrossRef]

58. Huang, D.; Ou, B.; Hampsch-Woodill, M.; Flanagan, J.A.; Prior, R.L. High-throughput assay of oxygen radical absorbance capacity (ORAC) using a multichannel liquid handling system coupled with a microplate fluorescence reader in 96-well format. J. Agric. Food Chem. 2002, 50, 4437-4444. [CrossRef]

59. Gaviria Montoya, C.; Ochoa Ospina, C.; Sánchez Mesa, N.; Medina Cano, C.; Lobo Arias, M.; Galeano García, P.; Mosquera Martínez, A.; Tamayo Tenorio, A.; Lopera Pérez, Y.; Rojano, B. Actividad antioxidante e inhibición de la peroxidación lipídica de extractos de frutos de mortiño (Vaccinium meridionale SW). Boletín Latinoam. Caribe Plantas Med. Aromáticas 2009, 8, 519-528.

60. Zapata Acosta, K.; Piedrahita, A.M.; Alzate, A.F.; Cortés, F.B.; Rojano, B.A. Oxidative stabilization of Sacha Inchi (Plukenetia Volubilis Linneo) oil with Mortiño (Vaccinium Meridionale SW) suspensions addition. Cienc. Desarro. 2015, 6, 141-153. [CrossRef]

61. Antonini, E.; Torri, L.; Piochi, M.; Cabrino, G.; Meli, M.A.; De Bellis, R. Nutritional, antioxidant and sensory properties of functional beef burgers formulated with chia seeds and goji puree, before and after in vitro digestion. Meat Sci. 2020, 161, 108021. [CrossRef]

62. Peiretti, P.G.; Gai, F.; Zorzi, M.; Aigotti, R.; Medana, C. The effect of blueberry pomace on the oxidative stability and cooking properties of pork patties during chilled storage. J. Food Process. Preserv. 2020, 44, e14520. [CrossRef]

63. Lorenzo, J.M.; Vargas, F.C.; Strozzi, I.; Pateiro, M.; Furtado, M.M.; Sant'Ana, A.S.; Rocchetti, G.; Barba, F.J.; Dominguez, R.; Lucini, L.; et al. Influence of pitanga leaf extracts on lipid and protein oxidation of pork burger during shelf-life. Food Res. Int. 2018, 114, 47-54. [CrossRef] [PubMed]

64. Rocchetti, G.; Bernardo, L.; Pateiro, M.; Barba, F.J.; Munekata, P.E.S.; Trevisan, M.; Lorenzo, J.M.; Lucini, L. Impact of a pitanga leaf extract to prevent lipid oxidation processes during shelf life of packaged pork burgers: An untargeted metabolomic approach. Foods 2020, 9, 1668. [CrossRef] [PubMed]

65. Selani, M.M.; Contreras-Castillo, C.J.; Shirahigue, L.D.; Gallo, C.R.; Plata-Oviedo, M.; Montes-Villanueva, N.D. Wine industry residues extracts as natural antioxidants in raw and cooked chicken meat during frozen storage. Meat Sci. 2011, 88, 397-403. [CrossRef] [PubMed]

66. Sadeghinejad, N.; Amini Sarteshnizi, R.; Ahmadi Gavlighi, H.; Barzegar, M. Pistachio green hull extract as a natural antioxidant in beef patties: Effect on lipid and protein oxidation, color deterioration, and microbial stability during chilled storage. LWT 2019, 102, 393-402. [CrossRef]

67. Faustman, C.; Sun, Q.; Mancini, R.; Suman, S.P. Myoglobin and lipid oxidation interactions: Mechanistic bases and control. Meat Sci. 2010, 86, 86-94. [CrossRef] [PubMed]

68. Pogorzelska, E.; Godziszewska, J.; Brodowska, M.; Wierzbicka, A. Antioxidant potential of Haematococcus pluvialis extract rich in astaxanthin on colour and oxidative stability of raw ground pork meat during refrigerated storage. Meat Sci. 2018, 135, 54-61. [CrossRef]

69. Holman, B.W.B.; van de Ven, R.J.; Mao, Y.; Coombs, C.E.O.; Hopkins, D.L. Using instrumental (CIE and reflectance) measures to predict consumers' acceptance of beef colour. Meat Sci. 2017, 127, 57-62. [CrossRef] [PubMed]

70. Ripoll, G.; Joy, M.; Muñoz, F.; Albertí, P. Meat and fat colour as a tool to trace grass-feeding systems in light lamb production. Meat Sci. 2008, 80, 239-248. [CrossRef] [PubMed]

71. Nassu, R.T.; Gonçalves, L.A.G.; Da Silva, M.A.A.P.; Beserra, F.J. Oxidative stability of fermented goat meat sausage with different levels of natural antioxidant. Meat Sci. 2003, 63, 43-49. [CrossRef] 
72. Jin, S.K.; Choi, J.S.; Yang, H.S.; Park, T.S.; Yim, D.G. Natural curing agents as nitrite alternatives and their effects on the physicochemical, microbiological properties and sensory evaluation of sausages during storage. Meat Sci. 2018, 146, 34-40. [CrossRef]

73. Albertos, I.; Martin-Diana, A.B.; Cullen, P.J.; Tiwari, B.K.; Ojha, K.S.; Bourke, P.; Rico, D. Shelf-life extension of herring (Clupea harengus) using in-package atmospheric plasma technology. Innov. Food Sci. Emerg. Technol. 2019, 53, 85-91. [CrossRef]

74. Wang, X.; Wang, Z.; Zhuang, H.; Nasiru, M.M.; Yuan, Y.; Zhang, J.; Yan, W. Changes in color, myoglobin, and lipid oxidation in beef patties treated by dielectric barrier discharge cold plasma during storage. Meat Sci. 2021, 176, 108456. [CrossRef]

75. de Carvalho, F.A.L.; Lorenzo, J.M.; Pateiro, M.; Bermúdez, R.; Purriños, L.; Trindade, M.A. Effect of guarana (Paullinia cupana) seed and pitanga (Eugenia uniflora L.) leaf extracts on lamb burgers with fat replacement by chia oil emulsion during shelf life storage at $2{ }^{\circ} \mathrm{C}$. Food Res. Int. 2019, 125, 108554. [CrossRef]

76. Tomasevic, I.; Djekic, I.; Font-i-Furnols, M.; Terjung, N.; Lorenzo, J.M. Recent advances in meat color research. Curr. Opin. Food Sci. 2021, 41, 81-87. [CrossRef]

77. GoÑi, V.; Indurain, G.; Hernandez, B.; Beriain, M.J. Measuring muscle color in beef using an instrumental method versus visual color scales. J. Muscle Foods 2008, 19, 209-221. [CrossRef]

78. Mello, R.; Vaz, F.N.; Pacheco, P.S.; Pascoal, L.L.; Prestes, R.C.; Costa, P.B.; Kipper, D.K. Predictive efficiency of distinct color image segmentation methods for measuring intramuscular fat in beef. Ciência Rural 2015, 45, 1865-1871. [CrossRef]

79. Wang, F.; Holman, B.W.B.; Zhang, Y.; Luo, X.; Mao, Y.; Hopkins, D.L. Investigation of colour requirements of frozen beef rolls by Chinese consumers for hot pot. Meat Sci. 2020, 162, 108038. [CrossRef] 